UNIVERSIDADE DE SÃO PAULO

FACULDADE DE ZOOTECNIA E ENGENHARIA DE ALIMENTOS

HELENA VIEL ALVES BEZERRA

Lignina purificada na dieta de ruminantes: impacto no desempenho e saúde de ovinos

Pirassununga

2019 
Lignina purificada na dieta de ruminantes: impacto no desempenho e saúde de ovinos

\section{Versão Corrigida}

Dissertação apresentada à Faculdade de Zootecnia e Engenharia de Alimentos da Universidade de São Paulo, como parte dos requisitos para a obtenção do título de Mestre em Ciências do programa de pósgraduação em Zootecnia.

Área de concentração: Qualidade e Produtividade Animal.

Orientador: Prof. Dr. Paulo Roberto Leme 
Ficha catalográfica elaborada pelo

Serviço de Biblioteca e Informação, FZEA/USP, com os dados fornecidos pelo(a) autor(a)

Viel Alves Bezerra, Helena

Lignina purificada na dieta de ruminantes: impacto no desempenho e saúde de ovinos / Helena Viel Alves Bezerra ; orientador Paulo Roberto Leme.

-- Pirassununga, 2019.

$75 \mathrm{f}$.

Dissertação (Mestrado - Programa de Pós-Graduação em Zootecnia) -- Faculdade de Zootecnia e

Engenharia de Alimentos, Universidade de São Paulo.

1. Ovinos. 2. Lignina purificada. 3. Estresse oxidativo. 4. Desempenho. 5. Saúde ruminal. I. Roberto Leme, Paulo, orient. II. Título. 


\title{
Lignina purificada na dieta de ruminantes: impacto no desempenho e saúde de ovinos
}

\author{
Dissertação apresentada à Faculdade de Zootecnia \\ e Engenharia de Alimentos da Universidade de São \\ Paulo, como parte dos requisitos para a obtenção do \\ título de Mestre em Ciências do programa de pós- \\ graduação em Zootecnia. \\ Área de concentração: Qualidade e Produtividade \\ Animal.
}

Data de aprovação:

Banca examinadora:

Prof. Dr. Paulo Roberto Leme

Faculdade de Zootecnia e Engenharia de Alimentos (FZEA/USP) - Presidente da banca.

Prof. Dr. Alexandre Vaz Pires

Escola Superior de Agricultura Luiz de Queiroz (ESALQ/USP)

Prof. Dr. Danilo Domingues Millen

Universidade Estadual Paulista (Unesp), Campus de Dracena.

Prof ${ }^{\text {a }}$. Dra. Sarita Bonagurio Gallo

Faculdade de Zootecnia e Engenharia de Alimentos (FZEA/USP) 


\section{DEDICATÓRIA}

Meus bons feitos serão sempre dedicados primeiramente a Deus, "porque dEle e por Ele, e para Ele, são todas as coisas; glória, pois, a Ele eternamente" (Rm 11:36).

Em especial aos meus pais, José Brauner Alves Bezerra e Dijane Viel Alves Bezerra, que nunca pouparam esforços para que nada me faltasse e me deram todo o apoio para que eu pudesse seguir da melhor forma a minha jornada.

Esta vitóría é de vocês!

Dedico. 


\section{AGRADECIMENTOS}

Primeiramente a Deus, que sempre guiou meus passos, me guardou e livrou, me deu sabedoria, saúde e força, e com suas mãos sempre me conduziu.

À Faculdade de Zootecnia e Engenharia de Alimentos da Universidade de São Paulo.

À Coordenação de Aperfeiçoamento de Pessoal de Nível Superior (CAPES) pela concessão e financiamento da bolsa de estudos durante o curso de mestrado.

Ao meu orientador, professor emérito, Dr. Paulo Roberto Leme, pela oportunidade que me concedeu em integrar sua equipe, que muito me engrandeceu como pessoa e profissional, compartilhando sua sabedoria e experiência, depositando confiança em meu trabalho.

À Prefeitura do Campus Fernando Costa na pessoa do Prof. Dr. Arlindo Saran Netto, igualmente ao Departamento de Zootecnia e ao Laboratório de Avaliação Animal e Qualidade de Carne (LAAQC - FZEA/USP) na pessoa do Prof. Dr. Saulo da Luz e Silva pela concessão de infraestrutura para que este experimento fosse executado, bem como pelo apoio científico.

À Prof ${ }^{a}$ Dra. Sarita Bonagurio Gallo por todo o apoio prestado com profissionalismo e solicitude durante a execução deste projeto e pelas lições compartilhadas com muita gentileza para que o experimento ocorresse da melhor maneira possível.

À Dra. Alessandra Fernandes Rosa pelo auxílio com as análises laboratoriais e de qualidade de carne e por compartilhar seu vasto conhecimento, contribuindo valiosamente na execução deste projeto e durante o curso de mestrado, pessoal e cientificamente.

Aos meus amados pais, Brauner e Dijane, por sempre terem me apoiado nas decisões e estarem ao meu lado sempre. São os grandes responsáveis por eu ser quem sou.

À minha avó Ivete e aos meus bisavós Orlando e Cida (in memoriam), por terem semeado em meu coração o grande amor pela vida no campo e pela pecuária.

Ao meu namorado Antonio Bordignon, pelo amor e companheirismo. Eu amo você!

Aos meus queridos tios Bira, Gil e Gina e aos meus primos Pâmela, Lara e Lucas pelo apoio, orações, torcida e momentos em família. 
Aos amigos de pós-graduação Vicente e Nara pelos conselhos, ajuda nas horas de trabalho, na condução do experimento e pelos momentos de descontração.

Às minhas queridas amigas e companheiras de trabalho Arícia e Érica por terem me ajudado com o experimento cuidando dos animais com carinho e responsabilidade, pelas horas mais cansativas de trabalho árduo e dedicação e pelos momentos de descontração.

Aos meus amigos e companheiros de longa data Fábio, Henrique e Lina por todos os conselhos e ajuda.

À minha amiga-irmã Julia David Lourenzon pela parceria.

Aos meus queridos companheiros de confinamento Paulinho e Lucas, pela dedicação.

Aos funcionários Ricardinho e Dione pela força e aos funcionários da fábrica de ração e do abatedouro.

À Suzano Papel e Celulose pelo fornecimento da lignina utilizada e avaliada no experimento.

Novamente o agradecimento especial vai para a minha família, pois sem eles eu jamais teria conseguido chegar até aqui! Minha eterna gratidão a todos vocês.

"A gratidão é a memóría do coração". 
"Animal experimental: sob o nosso controle ele cresce, depende e confia. Respeito haja, enquanto vivo, pois não será em vão seu sacrificio."

Ivan Sampaio. 


\section{RESUMO}

BEZERRA, H. V. A. Lignina purificada na dieta de ruminantes: impacto no desempenho e saúde de ovinos. 2019. 75f. Dissertação (Mestrado) Faculdade de Zootecnia e Engenharia de Alimentos, Universidade de São Paulo, Pirassununga, 2019.

Este estudo foi conduzido com o objetivo de avaliar a influência da lignina purificada como aditivo em dietas com elevada proporção de concentrado sobre desempenho, morfometria ruminal, características da carne e estresse oxidativo em cordeiros. Foram utilizados trinta e dois cordeiros cruzados da raça Dorper $X$ Santa Inês com peso vivo inicial e idade de $23 \pm 6,3 \mathrm{~kg}$ e 60 dias, respectivamente. Os animais foram mantidos em baias individuais, alimentados com dieta composta por $10 \%$ de volumoso (feno de capim "coastcross") e $90 \%$ de concentrado, e distribuídos em delineamento de blocos casualizados em um dos quatro tratamentos: controle (CTL), sem aditivos, monensina (MON), onde receberam a ração CTL e MON (15 mg/kg MS), lignina kraft (LKR), recebendo ração $C T L$ contendo $L K R(12,5 \mathrm{~g} / \mathrm{kg} M S)$; e selênio e vitamina $E(S e E)$, que consistiu na ração CTL com Selênio (Se) e vitamina E (0,33 mg/kg e $100 \mathrm{Ul} / \mathrm{kg}$, respectivamente). Os cordeiros tiveram o peso mensurado a cada 14 dias. Amostras de sangue foram coletadas antes do início dos tratamentos, aos 29 e 54 dias de estudo, para avaliar a atividade de enzimas antioxidantes. Após 55 dias de confinamento, os animais foram abatidos e a incidência de rumenites e morfometria de papilas foram avaliadas, bem como características de carcaça, da carne e vida de prateleira. Os dados foram analisados pelo modelo MIXED procedure do SAS 9.3, com nível de significância de 5\%. Nenhum efeito dos tratamentos foi observado sobre o desempenho ou características de carcaça. Os cordeiros que consumiram LKR tiveram maior incidência de rumenites $(P=0,03)$. Não houve interação entre tempo e tratamentos, nem efeito dos tratamentos sobre a atividade da maioria das enzimas avaliadas, no entanto, aos 29 dias de estudo, observou-se maior atividade de peroxidases no LKR em comparação ao MON $(P=0,005)$ e SeE $(P=0,015)$. Aos 29 dias de estudo, níveis mais baixos de catalase foram observados no MON em comparação com o CTL $(P=0,030)$. Aos 54 dias, o $M O N$ apresentou menor atividade comparado ao $\operatorname{SeE}(P=0,042)$. Para vida de prateleira, o SeE foi efetivo em manter a baixa oxidação lipídica, uma vez que apresentou os menores valores 
em todos os tempos de avaliação $(P=0,005)$. Não houve ação protetiva da lignina Kraft sobre a mucosa da parede ruminal e nenhum efeito positivo no desempenho, porém apresentou aumento da atividade das peroxidases.

Palavras-chave: Ovinos. Lignina purificada. Estresse oxidativo. Desempenho. Saúde ruminal. 


\section{ABSTRACT}

BEZERRA, H. V. A. Purified lignin in ruminant diet: impact on sheep performance and health. 2019. 75f. M. Sc. Dissertation - Faculdade de Zootecnia e Engenharia de Alimentos, Universidade de São Paulo, Pirassununga, 2019.

This study was carried out to evaluate the influence of purified lignin as an additive in diets with high concentrate content on performance, ruminal health, meat characteristics and oxidative stress control in lambs. Thirty two crossbreed Dorper X Santa Inês with an initial live weight and age of $23 \pm 6,3 \mathrm{~kg}$ and $60 \mathrm{~d}$, respectively, were kept in individual pens and fed a diet composed of coast cross hay (10\%) and concentrate (90\%). The experimental design was a randomized block with four treatments: control (CTL), without additives, monensin (MON), with $15 \mathrm{mg} / \mathrm{kg}$, Kraft lignin (LKR) containing $12.5 \mathrm{~g} / \mathrm{kg}$ of the product and selenium and vitamin E (SeE), with $0.33 \mathrm{mg} / \mathrm{kg}$ and $100 \mathrm{IU} /$ $\mathrm{kg}$, respectively. The lambs had the weight measured every 14 days. Blood samples were collected at the beginning of feeding, at 29 and 54 days to evaluate the activity of antioxidant enzymes. After 55 days of feed, the lambs were slaughtered and the incidence of rumenitis and papillary morphometry were evaluated, as well as carcass traits, meat characteristics and shelf life. The data was analyzed with the MIXED model of SAS 9.3 with a $5 \%$ level significance. No effect of treatments was observed for the performance or carcass traits. The animals fed LKR showed the highest number of animals with incidence of rumenitis $(P=0.03)$. There was no interaction between time and treatments, nor effect of treatments on the activity of most enzymes evaluated, but at the 29 days of feed, a higher peroxidases activity was observed in the LKR compared to the MON $(P=0.005)$ and SeE $(P=0.015)$. At the 29 days of feed, lower levels of catalase were observed in the MON compared to the CTL $(P=0.030)$. At 54 days of confinement, the MON showed less activity compared to $\operatorname{SeE}(P=0.042)$. The SeE was effective to maintain low lipid oxidation since it presented the lowest values at all times of shelf life $(P=$ 0.005). There was no protective action of the Kraft lignin on the mucosa of the ruminal wall, and no positive effect on performance but it increased the activity of peroxidases. 
Keywords: Sheep. Purified lignin. Oxidative stress. Performance. Ruminal health. 


\section{LISTA DE TABELAS}

Tabela 1 - Composição percentual das dietas com base na MS

Tabela 2 - Características de desempenho de cordeiros alimentados com dietas de alto concentrado com diferentes aditivos

Tabela 3 - Características de carcaça e qualidade da carne cordeiros alimentados com dietas de alto concentrado com diferentes aditivos

Tabela 4 - Incidência de ruminite e parâmetros de morfologia ruminal de cordeiros alimentados com dietas de alto concentrado com diferentes aditivos

Tabela 5 - Comportamento da cor $\left(L^{*}, a^{*}\right.$ e $\left.b^{*}\right)$ e peroxidação lipídica da carne de cordeiros alimentados com dietas de alto concentrado com diferentes aditivos durante o tempo exposição da prateleira

Tabela 6 - Parâmetros de estresse oxidativo no plasma e soro de cordeiros alimentados com dietas de alto concentrado com diferentes aditivos 


\section{SUMÁRIO}

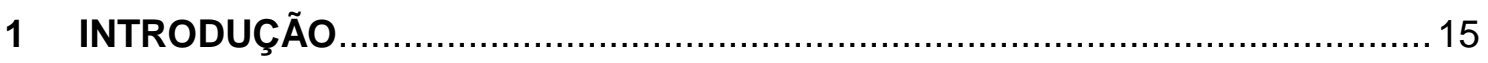

2 OBJETIVO

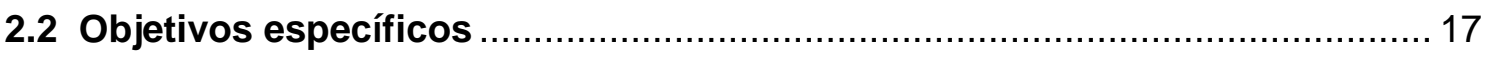

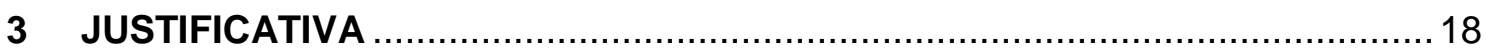

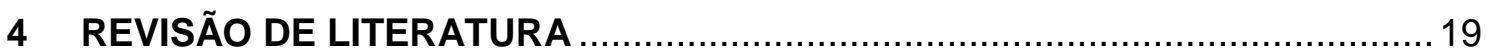

4.1 Dietas com elevada proporção de concentrado para ruminantes................... 19

4.2 Utilização de ionóforos na produção de ruminantes ...................................22

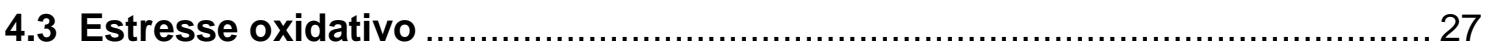

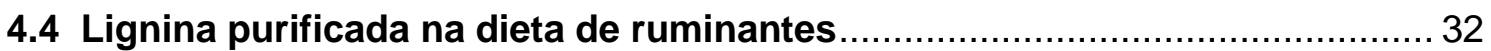

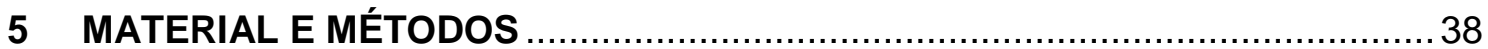

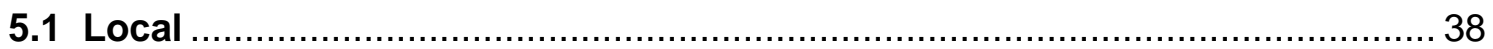

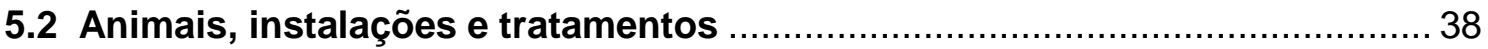

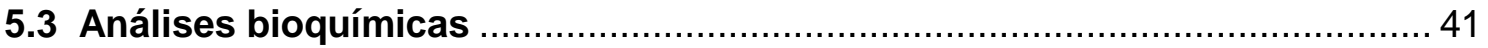

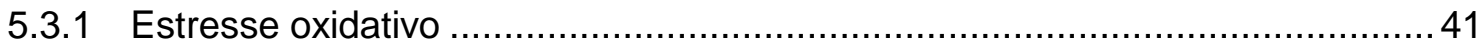

5.4 Abate, mensurações na carcaça e coleta de amostras ................................. 42

5.4.1 Cor, perdas por cocção, força de cisalhamento e tempo de prateleira ............43

5.4.2 Oxidação lipídica pela análise de substâncias reativas ao ácido tiobarbitúrico

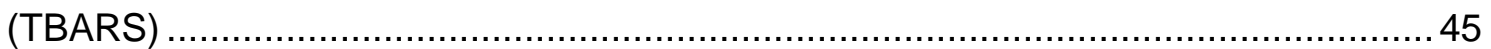

5.4.3 Análise de ruminite e parâmetros de morfologia ruminal ................................ 45

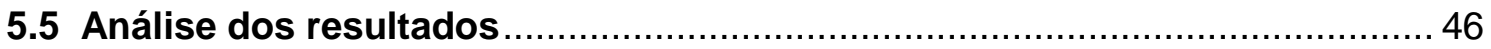

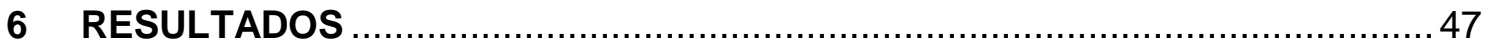

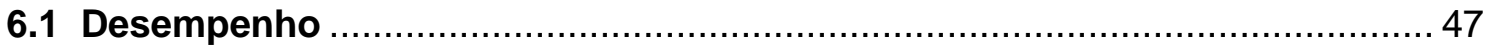

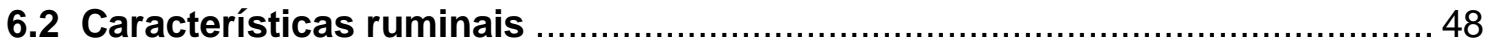

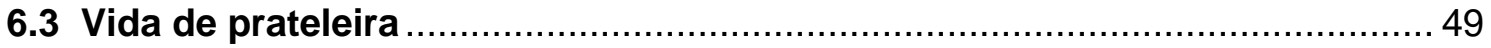

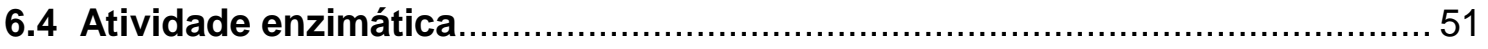

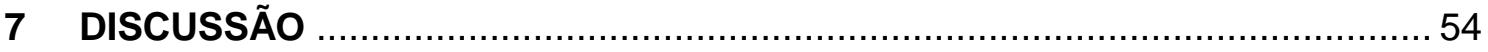

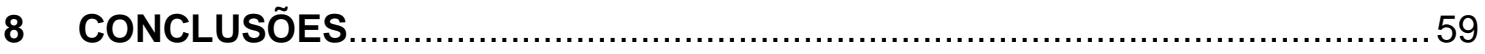

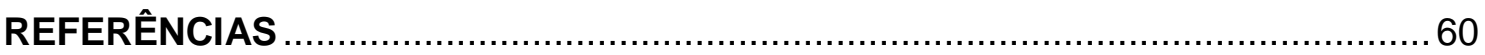

ANEXO 


\section{INTRODUÇÃO}

Nos sistemas de produção intensivos, os animais têm sido desafiados nutricionalmente através da utilização de dietas com elevada proporção de concentrado na fase de terminação, que permitem aumentar a produção de carne, evidenciam rápido ganho de peso, melhoram a eficiência alimentar e uniformização do produto final e reduzem o tempo para abate (GALLO et al., 2014).

No entanto, tais dietas podem ocasionar desordens metabólicas como a acidose ruminal (NAGARAJA; TITGEMEYER, 2007), e afetar a homeostase redox do organismo (CELI, 2010). Em animais de produção, o estresse oxidativo pode estar envolvido em várias condições patológicas que são relevantes para a produção animal e o bem-estar geral dos indivíduos (LYKKESFELDT; SVENDSEN, 2007).

A indústria vem sofrendo grande pressão do consumidor para reduzir a utilização de antibióticos e promotores de crescimento na dieta de animais de produção, por consequência da demanda de produtos seguros para consumo humano (CELI, 2010). Na busca por aditivos com princípios ativos que possam atuar na melhoria da conversão alimentar e do desempenho, bem como promover benefícios secundários, a utilização de extratos de plantas é uma nova alternativa nutricional para a produção pecuária (MAKKAR; FRANCIS; BECKER, 2007).

A lignina nativa é um polímero de alto peso molecular constituído de compostos fenólicos presentes na parede celular das plantas, que confere suporte estrutural, impermeabilidade e proteção. Globalmente, aproximadamente 50 a 100 milhões de toneladas de lignina são separadas da madeira durante os processos de fabricação de celulose e papel a cada ano. Contudo, apenas uma pequena porção $(10-20 \mathrm{~g} / \mathrm{kg})$ deste material é processada em produtos de valor agregado, sendo a maioria incinerada (GOSSELINK et al., 2004; LORA; GLASSER, 2002).

Sua forma purificada é obtida como um subproduto da indústria de celulose, separada da madeira através de diferentes processos químicos que resultam em diferentes tipos de lignina purificada, como a lignina Alcell e lignina Kraft. Em sua forma purificada, a lignina contém monômeros fenólicos de 
baixo peso molecular com efeitos biológicos que diferem da lignina nativa e não representa barreira de digestibilidade de nutrientes para animais ruminantes ou monogástricos (BAURHOO; PHILLIP; RUIZ-FERIA, 2008).

Estudos demonstraram resultados benéficos da utilização de ligninas purificadas na nutrição de ruminantes (OH-HARA et al., 1990; PHILLIP; IDZIAK; KUBOW, 2000; WANG et al., 2000) e de monogástricos (BAURHOO et al., 2007), e também sugeriram propriedades antioxidantes (AYYACHAMY et al., 2013; DONG et al., 2011; UGARTONDO; MITJANS; VINARDELL, 2008).

Diante do exposto, a premissa deste estudo foi avaliar os efeitos da lignina Kraft como aditivo comparado à monensina, ionóforo conhecido, e ao Selênio e vitamina E, antioxidantes conhecidos, sobre o desempenho, saúde ruminal, controle do estresse oxidativo e características da carcaça e da qualidade da carne de cordeiros alimentados com dietas com elevada proporção de concentrado. 


\section{OBJETIVO}

Avaliar o efeito da lignina Kraft sobre o desempenho, características de carcaça e qualidade de carne, bem como controle do estresse oxidativo de cordeiros alimentados com dietas com elevada proporção de concentrado.

\subsection{Objetivos específicos}

a) Verificar o efeito da lignina Kraft em comparação à monensina sódica, ionóforo conhecido, ao tratamento controle (sem aditivos) e aos antioxidantes convencionais (selênio e vitamina E) sobre as características produtivas, quantitativas e qualitativas da carcaça e da carne, como a ingestão de matéria seca, ganho de peso médio, rendimento de carcaça, área de olho de lombo, espessura de gordura subcutânea, $\mathrm{pH}$, cor, maciez, shelf life e peroxidação lipídica (TBARS), além de sua influência sobre a saúde ruminal através da avaliação da incidência de ruminite e morfologia de papilas.

b) Verificar os efeitos da lignina purificada como antioxidante em relação aos antioxidantes convencionais (selênio e vitamina E), ao controle (sem aditivos) e à monensina sódica, avaliando-se o controle do estresse oxidativo pela mensuração da atividade enzimática da glutationa peroxidase (GSH-Px), superóxido dismutase (SOD), catalase, peróxido de hidrogênio e peroxidases. 


\section{JUSTIFICATIVA}

Uma série de produtos classificados como aditivos está disponível no mercado a fim de contribuir com o melhor desempenho dos animais em crescimento e terminação, tendo como principais efeitos melhorar a conversão alimentar e ganho de peso, reduzir da incidência de acidose, timpanismo e coccidiose. Alguns possuem efeitos secundários, como ação antioxidante. Os benefícios de muitos aditivos já estão comprovados, porém existem vários produtos a serem experimentados para atestar o proveito do uso.

Suspeita-se que a lignina purificada pode ter aplicações nutricionais e terapêuticas na produção de ruminantes, além de propriedades antioxidantes devido à liberação de compostos fenólicos, sendo um potencial aditivo alimentar na nutrição animal. No entanto, a influência do uso da lignina Kraft como aditivo alimentar sobre o metabolismo e o desempenho de ruminantes precisa ser melhor elucidada para atestar o benefício do uso. 


\subsection{Dietas com elevada proporção de concentrado para ruminantes}

Os ruminantes desenvolveram adaptações evolutivas que, quando comparados fisiologicamente a herbívoros monogástricos, os tornam eficazes devido às suas estratégias anatômicas, fisiológicas e nutricionais. São beneficiados pelas vantagens potenciais do rúmen, sem restrições quanto à capacidade de consumo de alimentos, como outros herbívoros, uma vez que o mecanismo de separação de partículas do composto retículo-rúmen possibilita a retenção de parte do alimento que ainda requer maior digestão, ao mesmo tempo em que determina a passagem de material já digerido (CLAUSS; HUME; HUMMEL, 2010).

Os ruminantes domésticos possuem um alto grau de estratificação do conteúdo ruminal, que possui uma camada de gás, de partículas sólidas e de líquido, o que permite alta taxa de passagem do mesmo, e otimiza a produção de proteína microbiana (CLAUSS; HUME; HUMMEL, 2010). Dietas ricas em fibras acompanharam o processo evolutivo desses animais, uma vez que o hábito alimentar dos mesmos é composto em grande parte de forragens, sabendo-se que é necessário um mínimo de fibra para o bom funcionamento da fermentação ruminal e motilidade.

No entanto, devido às transformações da pecuária em relação aos sistemas de produção modernos e intensivos, principalmente com o aumento do número de animais terminados em confinamento, existe a necessidade do desenvolvimento de estratégias nutricionais com elevados níveis de concentrado no propósito de melhorar o desempenho produtivo, uniformizar o ganho de peso, a eficiência alimentar, aumentar a deposição de gordura de acabamento e promover efeitos no crescimento da carcaça e na qualidade de carne de animais confinados (SILVA, 2009).

O uso de dietas a base de milho inteiro e sem fonte de volumosos de fibra longa, ou até mesmo sem volumoso algum, vem ao encontro deste conceito, uma vez que busca o aumento no desempenho produtivo, permite a obtenção de maior eficiência de uso da energia metabolizável para ganho, em 
que maior parte da energia consumida é depositada no corpo, seja na forma de proteína ou gordura (CARDOSO, 2012; PAULINO et al., 2013).

De acordo com Galyean e Hubbert (2012), em confinamentos de bovinos de corte, a inclusão de pequeno percentual de fibra em dietas com elevada proporção de grãos ajuda a prevenir desordens metabólicas como a acidose, e a maximizar o consumo de energia líquida, possibilitando melhoria do desempenho zootécnico. Millen et al. (2009) realizaram uma pesquisa junto a nutricionistas em confinamentos de bovinos de corte no Brasil e encontraram que teor médio de volumoso utilizado em dietas de terminação era de $28,8 \%$, com variação de 12 a 45\%. A concentração de FDN média recomendada por esses nutricionistas foi de $26,4 \%$. São valores relativamente altos em comparação ao que é adotado por países em que a terminação em confinamento é mais empregada.

A utilização de dietas com elevada proporção de concentrado contribui com a independência do processo de obtenção de forragens, visto que a produção de silagens ou o corte do volumoso exige equipamentos e maquinários mais caros e específicos, além de extensas áreas para produzilos. Além disso, necessita-se de estrutura de armazenamento, planejamento antecipado e a ocorrência de problemas com maquinários e mão-de-obra são fatores limitantes para alguns confinadores, e também possui menor estabilidade no cocho e menor facilidade de manejo de oferta (CARDOSO, 2012).

Deve ser avaliado ainda o contexto do sistema de produção, pois essa estratégia de terminação pode proporcionar benefícios indiretos, como aumento da produtividade da propriedade, diluição de custos fixos, liberação de áreas de pastagens para outras categorias e emprego de novas tecnologias (FERNANDES et al., 2008).

No entanto, tais dietas, além de beneficiar a produtividade, também podem ocasionar efeitos deletérios no metabolismo. Portanto, é necessário um manejo alimentar adequado, uma vez que o fornecimento de dietas com alta proporção de carboidratos prontamente fermentescíveis pode ocasionar desordens metabólicas, sendo a mais comum a acidose ruminal (NAGARAJA; TITGEMEYER, 2007). 
Segundo Van Cleef (2009), a utilização de dietas com elevada proporção de concentrado leva a alterações na fisiologia ruminal, uma vez que a população de microrganismos pode ser alterada de acordo com a alimentação, além de afetar na taxa de passagem do alimento, motilidade e velocidade de absorção dos nutrientes. Estes fatores podem causar uma série de distúrbios metabólicos que podem acarretar em perda de eficiência e produção dos animais.

A acidose ruminal pode se apresentar na forma aguda ou crônica. $\mathrm{Na}$ forma aguda ocorre a ingestão exagerada de alimentos ricos em carboidratos, que fermentam rapidamente no rúmen, produzindo grandes quantidades de ácido láctico e ácidos graxos voláteis (AGVs), principalmente o propionato. Esta condição favorece a multiplicação do Streptococcus bovis que leva a produção de quantidades significativas de ácido láctico e a queda do $\mathrm{pH}(<5,5)$, comprometendo as bactérias Gram (-) e protozoários.

Quando o pH chega a valores inferiores a 5,0 ० S. bovis é inibido e ocorre a multiplicação do Lactobacillus sp. e a concentração de ácido láctico $D$ (-) e $L(+)$ aumentam significativamente no interior do rúmen, levando ao aumento da pressão osmótica e sequestro de líquido para a luz do órgão. $O$ conteúdo ruminal se torna aquoso e o animal apresenta hemoconcentração, desidratação, acidose metabólica, prostração, coma e possivelmente morte (DUNLOP, 1972; GARAY; GARCÍA, 2009; RADOSTITS et al., 2002).

$\mathrm{Na}$ forma crônica da acidose, observa-se ingestão prolongada de quantidades excessivas de carboidrato associada a teores baixos de fibra efetiva. A população microbiana ruminal se adapta à ração com elevada proporção de grãos e grandes quantidades de microrganismos usuários e produtores de lactato são detectadas. Desta forma, o ácido láctico não se acumula, pois é metabolizado pelas bactérias. Porém, as elevadas concentrações de AGVs principalmente butírico e propiônico estimulam a proliferação do epitélio das papilas ruminais e causa paraqueratose, o que leva a uma menor absorção dos ácidos graxos voláteis e aumenta a ocorrência de traumatismo e inflamações na parede do rúmen. Os efeitos sobre os animais são crônicos e insidiosos, a contínua carga ácida pode reduzir a eficiência metabólica e desempenho geral (SMITH, 2006). No momento do abate, se pode observar alguns sinais de desordens metabólicas como rumenites no 
epitélio ruminal e abscessos no fígado, sintomas associados à acidose (OWENS et al., 1998).

Compostos que afetam a homeostase redox do organismo podem ser liberados na corrente sanguínea, pelo consumo elevado de carboidratos prontamente fermentescíveis (CELI, 2010), devido à elevação do nível metabólico. Ao longo da conversão dos nutrientes em energia, ocorre a liberação dos radicais livres. Os mais abundantes em sistemas biológicos são os radicais livres centrados em oxigênio e seus metabólitos, também conhecidos como espécies reativas ao oxigênio (ERO). Dentre eles, podemos citar: peróxido de hidrogênio, hidroxila e o íon peróxido.

Aditivos como os antibióticos ionóforos são amplamente utilizados na indústria a fim de controlar acidose (NAGARAJA; LECHTENBERG, 2007). Os ionóforos atuam sobre bactérias produtoras de lactato, como o S.bovis e Lactobacillus spp., reduzindo a produção e acúmulo do ácido. A suplementação com esses produtos também reduz o consumo de alimento. Os ionóforos mais comumente utilizados são monensina, lasalocida e salinomicina. Outros antibióticos como tilosina e virginiamicina também possuem efeito inibitório sobre as bactérias Gram positivas produtoras de lactato no rúmen e podem ter efeito positivo no controle do $\mathrm{pH}$ ruminal (NAGARAJA, 2011).

$O$ estudo dos fatores metabólicos e nutricionais que afetam o estado oxidativo em ruminantes é uma interessante área de pesquisa, e crescentes estudos evidenciam as consequências fisiológicas e patológicas do estresse oxidativo em animais de produção. A indústria vem sofrendo grande pressão do consumidor para reduzir a utilização de antibióticos e promotores de crescimento na dieta de animais de produção, por consequência da demanda de produtos seguros para consumo humano (CELI, 2010).

\subsection{Utilização de ionóforos na produção de ruminantes}

A terminação em sistema de confinamento é uma das principais ferramentas utilizadas no objetivo de intensificação da criação de animais destinados à produção de carne, pois permite eficiência na mesma, reduzindo o tempo para terminação em detrimento de animais criados a pasto (NOTTER; KELLY; MCCLAUGHERTY, 1991). Considerando-se o processo de formação 
de proteína pelos animais e o custo da mesma, é necessário o uso de animais geneticamente superiores e a exploração de seu crescimento em diferentes fases através da alimentação e utilização de aditivos na dieta (RANGEL et al., 2008; SALMAN; PAZIANI; SOARES, 2006).

De acordo com Tedeschi, Fox e Tylutki (2003), a utilização de aditivos alimentares que melhorem a conversão de nutrientes e reduzam as perdas de energia nas rotas fermentativas é um importante instrumento para reduzir os impactos da pecuária no meio ambiente, além de contribuir com a melhoria na produtividade e promover economia de recursos. O uso de ionóforos na alimentação de ruminantes é uma das ferramentas mais estudadas e eficientes no tocante à manipulação da fermentação ruminal, uma vez que modula a mesma, com melhor eficiência de energia e utilização de nitrogênio proveniente da dieta.

Os ionóforos alteram as proporções molares de ácidos graxos de cadeia curta (AGCC) produzidos no rúmen (PERRY; BEESON; MOHLER, 1976), mitigam a produção de metano (RUSSEL; STROBEL, 1989), reduzem a deaminação e absorção de amônia, aumentando o influxo de proteína oriunda da dieta para o intestino delgado (BERGEN; BATES, 1984) e reduzem a ocorrência de distúrbios digestivos (McGUFFEY; RICHARDSON; WILKINSON, 2001) como acidose, cetose e timpanismo (NAGARAJA et al., 1997).

Os ionóforos são produtos da fermentação por bactérias do gênero Streptomyces sp., que manipulam a fermentação ruminal a fim de aumentar a produção de ácido propiônico, diminuir a produção de metano (que é responsável pela perda de 2 a 12\% da energia do alimento) e diminuir a proteólise e deaminação da proteína dietética no rúmen (SALMAN; PAZIANI; SOARES, 2006), sendo constituídos por moléculas que, segundo Pressman (1976), se ligam aos íons metálicos e auxiliam seu transporte através da membrana celular.

São classificados como antibióticos que reduzem ou inibem seletivamente o crescimento de microrganismos no rúmen, que interagem modificando a população microbiana, selecionando bactérias gram-negativas, produtoras de ácido propiônico, por estas serem resistentes aos ionóforos, e inibindo o crescimento das Gram-positivas, responsáveis pela produção dos ácidos acético, butírico e lático (GOMES, 2011). 
Segundo Russell e Strobel (1989), os ionóforos são moléculas classificadas como antibióticos pelo FDA (Food and Drug Administration), no entanto não são de uso compartilhado com seres humanos. Sua ação é através do transporte de íons, formando complexos lipossolúveis com cátions, permitindo sua passagem pela membrana lipídica de bactérias gram-positivas e protozoários do rúmen, interferindo no equilíbrio sódio-potássio celular.

Os ionóforos têm seu mecanismo de ação relacionado com a capacidade de alteração no fluxo de cátions através da membrana, que desencadeia uma reação de saída de $\mathrm{K}^{+}$e entrada de $\mathrm{H}^{+}$, levando a um acúmulo de $\mathrm{H}^{+}$no citoplasma das bactérias Gram-positivas, reduzindo o $\mathrm{pH}$. As bactérias utilizam mecanismo de transporte ativo para dissipar $\circ \mathrm{H}^{+}$intracelular, com gasto energético, reduzindo as reservas e a taxa de síntese de proteína, diminuindo a capacidade de divisão celular dos microrganismos (McGUFFEY et al., 2001). Assim, a utilização de ionóforos provoca um estado de letargia ou morte das bactérias através do mau funcionamento da bomba iônica que promove um desequilíbrio osmótico (RUSSELL; STROBEL, 1989).

Segundo Bergen e Bates (1984), em dietas com elevada proporção de carboidratos fermentescíveis, os ionóforos tendem a reduzir a ingestão de alimento, sem afetar o ganho de peso, melhorando a conversão alimentar. Isto se dá, aparentemente, pelo aumento da energia disponível, reduzindo o consumo através da regulação do balanço energético corporal, em que esta energia é convertida em ganho adicional (RANGEL et al., 2008).

Dentre os ionóforos utilizados na nutrição de ruminantes, o principal e mais estudado é a monensina sódica, um antibiótico carboxílico poliéter, inicialmente desenvolvido como coccidiostático empregado na alimentação de aves (MAGLIOCCA et al., 1994), sintetizada pela bactéria Streptomyces cinnamonensis (HANEY; HOEHN, 1967).

De acordo com McGuffey, Richardson e Wilkinson (2001), os benefícios da utilização da monensina sódica sobre a produção de ruminantes já estão consolidados, todavia, a maior parte das pesquisas realizadas avaliou seu uso em bovinos. A monensina sódica comercializada no Brasil não traz recomendações específicas para a utilização na espécie ovina, e poucos estudos avaliaram seus efeitos na terminação de ovinos (MARTINS et al., 2018). 
Segundo Novilla (1992), doses acima de $12 \mathrm{mg} / \mathrm{kg}$ de PC são tóxicas para ovinos devido ao intenso metabolismo de cálcio nas fibras musculares, de modo que a sobrecarga de $\mathrm{Ca}$ intracelular excede a capacidade homeostática e promove alterações degenerativo-necróticas na fibra muscular.

Martins et al. (2018) realizaram um levantamento a respeito das doses de monensina sódica utilizadas na maioria dos estudos com ovinos e encontraram que as mesmas variam de 22 a $33 \mathrm{mg} / \mathrm{kg} \mathrm{MS}$, que são inferiores ao nível de toxicidade.

Polizel et al. (2016) avaliaram os efeitos de doses de narasina em 45 cordeiros submetidos à uma dieta de $90 \%$ de concentrado e utilizaram como controle negativo uma dieta sem aditivos, e como controle positivo uma dieta contendo $25 \mathrm{mg}$ de monensina $/ \mathrm{kg}$ MS. Os autores verificaram que a narasina aumentou linearmente o GMD e a eficiência alimentar, no entanto, a utilização de $25 \mathrm{mg}$ de monensina sódica não afetou o desempenho dos animais quando comparado ao tratamento sem aditivos. Tal resultado gerou questionamento no tocante aos efeitos da monensina em cordeiros alimentados com dietas com elevada proporção de concentrado, particularmente em relação à dose utilizada.

O desempenho de 120 cordeiros alimentados com dietas contendo 0 , $5,5,11,22$ ou $33 \mathrm{mg}$ de monensina/kg MS foi avaliado por Nockels, Jackson e Berry (1978), e identificaram que os animais tratados com as doses de 5,5 e 11 $\mathrm{mg} / \mathrm{kg}$ MS apresentaram maior ganho de peso total, em detrimento dos animais tratados com as doses mais elevadas, que apresentaram resultados iguais em comparação ao tratamento controle. Os autores concluíram que a melhor dose de monensina sódica para cordeiros em terminação foi a de $5,5 \mathrm{mg} / \mathrm{kg}$, que aumentou seu ganho médio diário, e ainda ressaltaram que essa dose difere muito da dose recomendada para bovinos.

A inclusão de $0,5,10,20$ e $30 \mathrm{mg}$ de monensina $/ \mathrm{kg}$ na dieta de 300 cordeiros foi avaliada por Joyner et al. (1979), e observou-se que a menor dose de monensina ( $5 \mathrm{mg} / \mathrm{kg}$ ) reduziu conversão alimentar em comparação ao controle. Os autores também avaliaram a calorimetria respirométrica em 12 cordeiros, que foram alimentados com 0,10 ou $20 \mathrm{mg}$ de monensina $/ \mathrm{kg}$ MS. Observaram a redução na perda de energia através das fezes, urina e metano nos animais alimentados com 10 e $20 \mathrm{mg} / \mathrm{kg}$. Isto é, as doses mais baixas (5 
ou $10 \mathrm{mg} / \mathrm{kg}$ ) demonstraram resultados satisfatórios quanto utilizadas em dietas de ovinos.

No levantamento realizado por Martins et al. (2018), encontra-se que a dose de $25 \mathrm{mg} / \mathrm{kg}$ MS para ovinos, muito usada em experimentos de terminação de cordeiros, não traz benefícios em relação a fermentação ruminal, digestibilidade dos nutrientes e desempenho animal, e são citados trabalhos das décadas de 70 e 80 onde foram obtidos resultados positivos na fermentação ruminal, aumentando a eficiência energética dos animais e o desempenho e eficiência alimentar de cordeiros com doses menores (5,5 a 10 $\mathrm{mg} / \mathrm{kg} \mathrm{MS}$ ). Em um desses trabalhos (HORTON; STOCKDALE, 1981) testaram diferentes níveis do aditivo (0, 11, 22 e $33 \mathrm{mg} / \mathrm{kg} \mathrm{MS}$ ) em 96 cordeiros alimentados com uma dieta à base de cevada e farelo de alfafa, e verificaram que as respostas de desempenho foram melhores sob a dose de $11 \mathrm{mg} / \mathrm{kg}$ MS.

Polizel et al. (informação pessoal) ${ }^{1}$ testaram diferentes doses de monensina sódica $(0,8,16$ e $24 \mathrm{mg} / \mathrm{kg} \mathrm{MS})$ em cordeiros alimentados com elevada proporção de concentrado e observaram efeito quadrático para GMD e EA, consequentemente para o peso final, e concluíram que a dose de $8 \mathrm{mg} / \mathrm{kg}$ MS resulta em melhor desempenho para cordeiros. 


\subsection{Estresse oxidativo}

Ao longo da conversão dos nutrientes em energia, ocorre a liberação dos radicais livres. Os mais abundantes em sistemas biológicos são os radicais livres centrados em oxigênio e seus metabólitos, também conhecidos como espécies reativas ao oxigênio (ERO). ERO é um termo coletivo que inclui não apenas radicais livres centrados no oxigênio, como ânion superóxido e radical hidroxila, mas também alguns derivados não radicais de oxigênio, como peróxido de hidrogênio, e ácido hipocloroso (REILLY; SCHILLER; BULKLEY, 1991).

As ERO são continuamente liberadas no organismo como subprodutos normais do metabolismo celular e, em baixas concentrações, são essenciais para diversos fatores e processos fisiológicos, incluindo fosforilação de proteínas, transcrição e ativação de fatores, diferenciação celular, apoptose, maturação do ovócito e esteroidogênese e atuam no sistema imune combatendo antígenos, sendo eles altamente reativos na oxidação de agentes que destroem microrganismos, operando na resposta de defesa celular (AGARWAL; GUPTA; SHARMA, 2005; DRÖGE, 2002; MILLER; BRZEZINSKASLEBODZINSKA; MADSEN, 1993).

Sua ação é regulada por antioxidantes que controlam as concentrações desses compostos. Se a concentração dos antioxidantes estiver igual ou acima da concentração de oxidantes, as células estão protegidas. Porém, na ocorrência de um desequilíbrio, ocasionando um aumento da concentração de oxidantes, ocorrerá o estresse oxidativo, que é como se denomina a liberação em excesso desses radicais livres no organismo. $O$ estresse oxidativo ocorrerá quando o excesso de produção não puder ser neutralizado por mecanismos antioxidantes, levando potencialmente a alterações patológicas (LYKKESFELDT; SVENDSEN, 2007).

Tais excessos podem ocasionar danos à funcionalidade celular, prejudicando os lipídeos celulares, proteínas e o DNA, podendo afetar o animal em condições sanitárias ou produtivas (SUGINO, 2006; CELI, 2010).

Quando as ERO não são eficazmente removidas, o estresse oxidativo pode prejudicar a saúde. Diretamente, os efeitos incluem danos peroxidativos a importantes lípideos e macromoléculas. Indiretamente, alterações induzidas 
pelas ERO em membranas celulares e componentes podem modificar vias metabólicas, resultando em fisiologia alterada e possivelmente patologia (MILLER; BRZEZINSKA-SLEBODZINSKA; MADSEN, 1993).

A imparidade do desempenho animal causada pelas ERO pode estar relacionada tanto ou mais ao metabolismo alterado do que com danos reais nas células. A defesa antioxidante e as reações catalisadas por enzimas esteroidogênicas requerem equivalentes redutores fornecidos pelo NADPH (BHAGAVAM, 1978; SIES, 1985). O consumo excessivo de redutores equivalentes pelo estresse devido aos radicais livres pode diminuir o NADPH2 e aumentar as concentrações de NADP apesar da atividade da derivação monofosfato, que gera a forma reduzida (GOLDEN; RAMDATH, 1987).

$O$ consumo de redutores equivalentes pelas reações das ERO pode diminuir a oferta de NADPH disponível para importantes processos fisiológicos. Adicionalmente, a indução da derivação de monofosfato por aumento do desequilíbrio das ERO pode desviar a glicose de outras vias. Essa possibilidade pressupõe maior importância quando a exigência de glicose e a quantidade disponível no ruminante são consideradas (MILLER; BRZEZINSKASLEBODZINSKA; MADSEN, 1993).

Vários mecanismos de defesa estão disponíveis para prevenir danos oxidativos, incluindo sistemas de eliminação, como as enzimas glutationa peroxidase (GSH-Px) e a superóxido dismutase (SOD). Além disso, os grupos tiol, comumente encontrados na cadeia lateral da cisteína, são os sítios quimicamente mais reativos em proteínas, como a albumina, e possuem fortes propriedades redutoras (MORAN; GUTTERIDGE; QUINLAN, 2001; SORIANI; PIETRAFORTE; MINETTI, 1994).

Os antioxidantes endógenos podem ser divididos em três grupos principais (MILLER; BRZEZINSKA-SLEBODZINSKA; MADSEN, 1993). O primeiro grupo compreende antioxidantes enzimáticos, incluindo superóxido dismutase (SOD) e glutationa-peroxidase (GSH-Px), e representa a principal forma de defesa antioxidante intracelular. A atividade da GSH-Px no plasma contribui para a defesa oxidativa de tecidos animais catalisando a redução de peróxidos de hidrogênio e lipídios (HALLIWELL; CHIRICO, 1993) e também é considerada um indicador de estresse oxidativo (TÜZÜN et al., 2002). A GSHPx funciona em reações de redução da oxidação celular para proteger a 
membrana celular do dano oxidativo causado por radicais livres (FLOHE; GUNZLER; SCHOCK, 1973).

O selênio é um componente estrutural de proteínas específicas denominadas selenoproteínas. Estas são agrupadas em cinco glutationa peroxidases (GPx), três deiodinases, três tioredoxina redutases, selenofosfato sintetase, selenoproteína $P$, selenoproteína W, 15kDa-selenoproteína e 18kDaselenoproteína (BEHNE; KYRIAKOPOLUS, 2001; KÖHRLE, 2000). As enzimas peroxidases possuem como função proteger as células do dano oxidativo e assegurar a integridade de membrana. As membranas particularmente em risco incluem as células vermelhas do sangue e as células gastrintestinais (BEHNE; KYRIAKOPULOS, 2001).

Assim como a GSH-Px, a enzima SOD é classificada como um antioxidante endógeno, que catalisa a reação de dismutação do superóxido em peróxido de hidrogênio $\left(\mathrm{H}_{2} \mathrm{O}_{2}\right)$, e de acordo com Halliwell e Chirico (1993), é considerada a primeira defesa contra os pro-oxidantes. Uma vez que a SOD aumenta a produção de $\mathrm{H}_{2} \mathrm{O}_{2}$, as células somente estarão protegidas com 0 aumento simultâneo da atividade da enzima catalase e da GHS-Px (FREI, 1994; KEHRER; SMITH, 1994).

A catalase tem como função catalisar a reação de redução do peróxido de hidrogênio produzido pela SOD em duas moléculas de $\mathrm{H}_{2} \mathrm{O}$ e uma de $\mathrm{O}_{2}$. Uma vez que a GSH-Px é relacionada diretamente com a remoção do peróxido de hidrogênio durante a reação de dismutação das ERO, é esperada uma redução simultânea nos níveis dos mesmos (DRÖGE, 2002).

Estudos em ovinos mantidos a pasto indicaram que a atividade da GSH-Px é influenciada pelas características do solo e da pastagem e pela estação (ANDRÉS et al., 1997; ANDRÉS et al., 1999. Uma vez que a atividade da SOD aumenta a produção de $\mathrm{H}_{2} \mathrm{O}$, a proteção contra o oxigênio reativo seria dada apenas por um aumento simultâneo nas atividades de catalase e GSH-Px e disponibilidade de glutationa (FREI, 1994; KEHRER; SMITH, 1994).

Estudos em cabras leiteiras mostraram que as concentrações de albumina no plasma são significativamente reduzidas durante o verão (DI TRANA et al., 2006). Esta informação é bastante relevante considerando que a albumina faz parte do conjunto antioxidante, sendo um eliminador de 
radicais livres (HALLIWELL, 1988). A albumina é sintetizada exclusivamente pelo fígado e é a principal fonte de $\mathrm{SH}$ (tióis proteicos) plasmático. A redução da função hepática, geralmente observada no período pós-parto, pode explicar níveis plasmáticos e de albumina mais baixos. Estudos em vacas leiteiras confirmaram o papel antioxidante desempenhado pela albumina particularmente perto do parto, quando os animais geralmente não recebem suplementação vitamínica / mineral (CASTILLO et al., 2005).

O terceiro grupo é representado pelos antioxidantes não enzimáticos de baixo peso molecular, e é encontrado principalmente no plasma, mas também em outros fluidos extracelulares e intracelulares. A capacidade antioxidante primária do soro é derivada de antioxidantes não enzimáticos, como a glutationa (GSH), o $\alpha$-tocoferol, $\beta$-caroteno e ácido úrico (HALLIWELL; GUTTERIDGE, 1989). Em particular, o GSH desempenha um papel importante na proteção de células contra o estresse oxidativo e agentes tóxicos. Atua como substrato ou co-substrato em reações enzimáticas e também reage diretamente com radicais livres e peróxidos lipídicos (BRIVIBA; SIES, 1994).

Apesar dos importantes papéis biológicos das ERO, se presentes no organismo em elevadas quantidades, sua ação passa a ser responsável por danificar as células do animal, causando danos especialmente aos ácidos graxos poliinsaturados das membranas fosfolipídicas da célula, resultando em peroxidação dos lipídeos e alterações na qualidade da carne, seja ela exsudativa ou de nutrientes (OLIVO, 2006). O malondialdeído (MDA) é um dos vários produtos finais de baixo peso molecular, formado durante a decomposição induzida por radicais de ácidos graxos poliinsaturados. O MDA reage prontamente com 0 ácido tiobarbitúrico produzindo um pigmento avermelhado que pode ser facilmente medido por espectrofotometria na forma de substâncias reativas ao ácido tiobarbitúrico (TBARS) (JANERO, 1990).

Pode-se observar que para a mensuração do estresse oxidativo, faz-se necessário efetuar um conjunto de análises referentes aos antioxidantes e pró-oxidantes para se atingir parâmetros significativos a respeito da homeostase redox do animal.

Existe um crescente interesse no papel do estresse oxidativo sobre as doenças de ruminantes devido à ligação entre a defesa antioxidante e os 
sistemas imunológicos de humanos e não ruminantes (JACOB, 1995; SIES; STAHL; SUNDQUIST, 1992).

De acordo com Lykkesfeldt e Svendsen (2007), os primeiros estudos a respeito da relação do estresse oxidativo com doenças em animais de produção foram realizados em suínos, bovinos de corte e equinos, focando nos níveis de ascorbato e produção de óxido nítrico. Estudos em suínos e bovinos têm sido esporádicos e, principalmente a respeito de doenças infecciosas como pneumonia, enterite, mastite, endometrite e sepse. Estudos em equinos, em particular cavalos de corrida e cavalos com obstrução das vias aéreas foram mais minuciosos, incluindo avaliação de obstrução recorrente das vias aéreas, hemorragia pulmonar induzida por exercício, laminite, artrite e estrangulamento intestinal.

O estresse oxidativo pode contribuir para o início de distúrbios no periparto em vacas de leite (MILLER; BRZEZINSKA-SLEBODZINSKA; MADSEN, 1993). Também se relatou que vacas expostas a estresse térmico moderado (temperatura retal de 39,5 $\pm 0,2{ }^{\circ} \mathrm{C}$ ) como resultado de índice de temperatura e umidade alta no verão apresentaram maior atividade de SOD eritrocitária, GSH-Px, tióis intracelulares e substâncias reativas ao ácido tiobarbitúrico em comparação a vacas paridas na primavera; estes dados fornecem evidências de estresse oxidativo em vacas em fase de lactação nos meses quentes de verão em climas tropicais (INGRAHAM; STANLEY; WAGNER, 1979).

Chirase et al. (2004) avaliaram o estresse causado pelo transporte em bezerros e encontraram 0 aumento das concentrações séricas de biomarcadores de estresse oxidativo, que estão relacionados a episódios de doença respiratória bovina e mortalidade. Em contrapartida, Hutcheson e Cole (1985) constataram que a suplementação de bezerros com vitamina E (800 a $1.600 \mathrm{Ul} /$ bezerro / d) reduziu em $12 \%$ a $27 \%$ a incidência de doença respiratória bovina e influenciou positivamente no desempenho através do aumento do ganho médio diário de peso.

Os efeitos deletérios do estresse oxidativo na produção estão concentrados em características sanitárias, produtivas e reprodutivas dos animais e também na qualidade da carne. Para que o produto final mantenha sua qualidade até chegar à mesa do consumidor, é necessário que a carne 
mantenha sua capacidade de resistir aos processos deteriorantes dos nutrientes, como a oxidação lipídica e proteica.

A peroxidação lipídica pode afetar a estrutura e função das membranas em vários aspectos, reduzindo o conteúdo relativo de ácidos graxos poliinsaturados, formando peróxidos lipídicos que podem estimular ou inibir a conformação de proteína na membrana, produzir tióis oxidantes que podem afetar as atividades enzimáticas, reduzir da fluidez lipídica na membrana e liberar produtos de degradação do local pela peroxidação lipídica (AMES; SHIGENAGA; HAGEN, 1993), afetando a qualidade da carne e o tempo de prateleira do produto final (LAWRIE, 2005).

A utilização de antioxidantes também pode apresentar efeitos significativos no produto post mortem. A ministração de antioxidantes

dietéticos apresenta melhores efeitos em relação aos ministrados após 0 abate (KERRY et al., 1999). A utilização de minerais como o selênio, cobre, vitaminas $E$ e $C$, entre outros, se mostra eficaz no controle do estresse oxidativo (CELI, 2010).

O uso de alimentos alternativos naturalmente ricos em antioxidantes, de acordo com Martin e Kadokawa (2006), é uma nova ferramenta de gerenciamento ética e de fácil utilização. O efeito da suplementação dietética com antioxidantes em ruminantes não foi totalmente avaliado, necessitando de maiores investigações a respeito do papel e da atividade de antioxidantes naturais não comumente presentes nas dietas (CELI, 2010).

\subsection{Lignina purificada na dieta de ruminantes}

Atualmente, existem vários produtos disponíveis no mercado para serem usados como aditivo na alimentação de animais de produção, e também existe uma crescente preocupação pública com o uso de antibióticos na alimentação, pois esta prática pode contribuir para o aparecimento de bactérias resistentes. A União Europeia impôs uma proibição total ao uso de antibióticos como promotores de crescimento em 2006 e há crescente pressão sobre a cadeia produtiva em todo o mundo para restringir o uso sub-terapêutico das substâncias (WANG et al., 2000). No entanto, seu uso terapêutico é permitido. Os compostos naturais de plantas vêm sendo estudados como alternativas aos 
antibióticos, e mostraram que compostos secundários como polifenóis e saponinas possuem fortes atividades antiparasitárias (BAE et al.,1993; McALLISTER et al., 1994; WANG et al., 2000).

A lignina compreende um grupo de polímeros fenólicos que são componentes essenciais da estrutura da parede celular dos vegetais, compondo cerca de um terço da mesma (PAN et al., 2006). Segundo Boudet e Grima-Pettenati (1996), é o segundo composto natural mais abundante depois da celulose no planeta Terra. É essencial como suporte mecânico para lâminas de folhas e caules, e confere resistência e rigidez às paredes das plantas. A lignina também atua como uma barreira física contra pragas e doenças (VANCE; KILRK; SHERWOOD, 1980).

Mundialmente, cerca de 50 a 100 milhões de toneladas de lignina são separadas da madeira durante a fabricação de papel e celulose a cada ano. No entanto, apenas uma pequena porção ( $1 \%$ a $2 \%$ ) deste material é processada em produtos de valor agregado, sendo a maior parte incinerada (GOSSELINK et al., 2004; LORA; GLASSER, 2002). Na nutrição animal, a lignina é considerada principalmente uma barreira para a digestibilidade. Existem utilizações da mesma pela indústria de alimentação animal como aglutinante para rações peletizadas (BAURHOO; PHILLIP; RUIZ-FERIA, 2007).

Acredita-se que a lignina interfira na degradação microbiana dos polissacarídeos de fibra, atuando como uma barreira física, e por ligações cruzadas com os polissacarídeos. Vários tipos de células de gramíneas tornam-se lignificadas durante a maturação, enquanto as células do xilema são os únicos tecidos lignificados em leguminosas (WILSON, 1993).

As fortes ligações de carbono-carbono e éter na lignina a tornam resistente à degradação. Por essa razão, a lignina é geralmente aceita como o principal fator responsável por limitar a digestão de forragens, reduzindo assim seu valor nutricional (BESLE; CORNU; JOUANY, 1994; VAN SOEST, 1994).

$\mathrm{Na}$ madeira, a lignina é fortemente entrelaçada com a celulose e a hemicelulose por forças não covalentes ou ligações covalentes para formar complexos de carboidratos (PEREZ et al., 2002), e não existe em uma forma pura (LAWOKO; HENRIKSSON; GELLERSTEDT, 2005). Na indústria de fabricação de papel, a lignina purificada é recuperada como um subproduto da produção de celulose durante a sulfitação de madeira. Entretanto, diferenças 
nos tratamentos de sulfitação produzem diferentes fragmentos de lignina (BAURHOO; PHILLIP; RUIZ-FERIA, 2007).

No processo sulfito, o ácido sulfúrico é usado para converter a lignina em lignosulfonatos. O processo Kraft, que utiliza hidróxido de sódio e sulfeto de sódio para extrair lignina da celulose nas fibras de madeira, é mais eficiente e produz fibras mais resistentes. Em contraste, o processo Alcell interrompe a integridade química da lignina nativa, produzindo assim fragmentos purificados de lignina como um co-produto (PYE, 1996). Este processo envolve etanol aquoso como licor de cozimento a temperaturas entre 185 e $195^{\circ} \mathrm{C}$.

Assim, a lignina, em sua forma purificada, possui estruturas químicas que diferem da lignina nativa. Por esta razão, a lignina purificada pode conter propriedades biológicas não características da lignina nativa. A lignina purificada é usada principalmente para fins industriais e de construção, e não tem aplicação conhecida e consolidada na produção animal (BAURHOO; PHILLIP; RUIZ-FERIA, 2007).

O processo Kraft de produção de celulose de eucalipto consiste em um pré-tratamento realizado no cavaco do eucalipto, onde hidróxido de sódio e sulfeto de sódio em solução são os reagentes químicos utilizados para extrair a lignina da madeira. O processo de extração desta lignina corresponde na quebra de ligações alfa-O-4 e Beta-O-4 da macromolécula de lignina, liberando os chamados molignóis (unidades fenilpropano).

Ocorre então, a liberação de compostos fenólicos de baixo peso molecular. Devido à lignina ser uma macromolécula complexa, seu mecanismo de "extração" da parede celular da biomassa pelo processo kraft ainda é baseado em hipóteses.

O ácido pirolenhoso é um líquido marrom liberado da madeira após a extração, produzido pela destilação de madeira na ausência de ar. Quando o gás gerado pela combustão é resfriado, ele se condensa em líquido. A carbonização de muitos tipos diferentes de madeira pode ser usada para produzir vários ácidos pirolenhosos, incluindo eucaliptos, carvalho, bambu, mangue, casca de coco e macieiras (AMEM-CHEN; PAKDEL, 1977; GUILLÉN; MANZANOS, 2002; LOO; JAIN; DARAH, 2007; LOO; JAIN; DARAH, 2008; PIMENTA et al., 2000; WITITSIRI, 2011). 
Muitas fontes diferentes de ácido pirolenhoso foram reconhecidas como inibidores seguros e naturais com várias atividades biológicas, como aplicações antifúngicas, termiticidas e repelentes. Além disso, o ácido pirolenhoso exibe um alto grau de atividade antimicrobiana contra vários microrganismos, juntamente com atividade antioxidante significativa (AMENCHEN; BAIMARK; NIAMSA, 2009; HWANG et al., 2005; MA et al., 2011;; VAN BERGEN et al., 2000; VELMURUGAN; HAN; LEE, 2009).

Através da pirólise da lignina, diversas frações químicas de classes diferentes são liberadas: aldeídos, cetonas, álcoois; ácidos; ésteres; derivados de furano e pirano; derivados fenólicos; hidrocarbonetos e compostos nitrogenados. Entre eles, a fração fenólica provavelmente representa a mais importante, tanto do ponto de vista qualitativo quanto quantitativo. Esta fração é constituída principalmente por fenol, 2-metoxifenol (guaiacol), 2,6-dimetoxifenol (siringol) e seus derivados, e por di-hidroxibenzenos (GUILLÉN; MANZANOS, 1996; GUILLÉN; IBARGOITIA, 1999).

O guaiacol é um produto natural fenólico isolado pela primeira vez da resina Guaiac e pela oxidação da lignina. Contém um grupo metoxi e é o éter monometílico do catecol. É facilmente oxidado pelo ferro heme das peroxidases, incluindo a peroxidase das enzimas ciclo-oxigenase (COX). Portanto, serve como um co-substrato redutor para reações de COX. É um óleo aromático amarelado que agora é comumente derivado de guaiacum ou creosoto de madeira. É usado na medicina humana como expectorante, antisséptico e anestésico local (THE HUMAN..., 2019)

O guaiacol é utilizado na sedação pulpar ductal tradicional na odontologia e tem a propriedade de induzir a proliferação celular; é um potente eliminador de radicais reativos de oxigênio e sua atividade sequestradora de radicais pode estar associada ao seu efeito na proliferação celular. É usado na preparação de vanilina sintética. Também está presente na fumaça da madeira, como um produto da pirólise da lignina (HMDB, 2019).

Assim como outros compostos fenólicos, o guaiacol possui propriedades analgésicas (HIRAFUJI, 1984; PARK et al., 2009), antioxidantes (MIMURA et al., 2005; GALANO; LÉON-CARMONA; ALVAREZ-IDABOY, 2012), antimicrobianas (BURT, 2004; LIU et al., 2011). 
Dependendo de sua concentração, o guaiacol pode ser citotóxico, e por ser um fenol substituído, é um ácido fraco que pode ser corrosivo aos tecidos (TISSERAND; YOUNG, 2014). Tem sido utilizado na alimentação de ruminantes como um dos componentes de produtos comerciais que utilizam em sua mistura óleos essenciais, como o Crina ${ }^{\circledR}$ Ruminants, composto por uma mistura de óleo de timol, eugenol, vanilina, guaiacol e limoneno (CASTILLEJOS et al., 2005; MCINTOSH et al., 2003).

Tal como o guaiacol, o siringol e seus derivados são produtos característicos da pirólise da lignina, sendo por isso um dos principais componentes do fumo de madeira, responsável pelo aroma da fumaça durante a pirólise (RODRIGUES, 2014). É conhecido por suas propriedades sensoriais, antioxidantes e antimicrobianas (MILLY; TOLEDO; RAMAKRISHNAN, 2004).

Estudos relacionados à utilização de polifenóis na medicina humana têm sugerido que os mesmos podem exercer diversos benefícios à saúde, como a inibição da oxidação de lipoproteínas de baixa densidade e redução do risco de doenças cardíacas (HEINONEN; MEYER; FRANKEL, 1998; MEYER et al., 1997), além de propriedades antiinflamatórias e anticarcinogênicas, bem como serem efetivos antioxidantes de lipídios nos alimentos (MIYAKE et al., 1999; SHAHIDI; WANASUNDARA, 1992; WANG et al., 1999).

Oh-Hara et al. (1990) e Phillip, Idziak e Kubow (2000) sugeriram que a lignina semi-purificada de biorrefinas lignocelulósicas pode ter tanto aplicações antimicrobianas quanto nutricionais na produção de bovinos de corte.

Phillip, Idziak e Kubow (2000) observaram que a lignina Alcell (12,5 $\mathrm{g} / \mathrm{kg}$ de MS) melhorou o ganho de peso dos bezerros holandeses mas, nenhum benefício foi observado ao aumentar os níveis de lignina na dieta (25 ou 50 $\mathrm{g} / \mathrm{kg}$ ).

Ricke et al. (1982) avaliaram que a indulina, uma lignina Kraft purificada da indústria de papel (40 e $80 \mathrm{~g} / \mathrm{kg}$ de MS), melhorou o ganho de peso e a eficiência alimentar de frangos de corte.

Baurhoo, Phillip e Ruiz-Feria (2007) notaram que a adição de baixos níveis de lignina na dieta $(1,25 \%)$ aumentou a altura das vilosidades, o número de células caliciformes (responsáveis pela secreção da mucina), e a população de bactérias benéficas (Lactobacillus sp. e Bifidobacterium sp.) no ceco intestinal de frangos de corte, apresentando também uma tendência em reduzir 
a população de E. coli nos excrementos. Phillip, Phillip e Ruiz-Feria (2000) observaram uma melhora no crescimento de bezerros suplementados com lignina (Alcell lignina) ao nível de $12,5 \mathrm{~g} / \mathrm{kg}$ de MS.

Wang et al. (2000) observaram uma melhora linear da eficiência alimentar de cordeiros submetidos a uma dieta a base de grãos e adição de lignina purificada, sem alteração no crescimento e características de carcaça, além de constatar um aumento na digestão ruminal da dieta e reduzir a produção de metano. A lignina purificada $(15 \mathrm{~g} / \mathrm{kg}$ de MS) de palha de trigo (lignina desidratada com hidróxido de sódio) aumentou a eficiência alimentar de cordeiros em $9 \%$.

Wang, McAllister e Lora (2017) constataram que a adição de lignina na dieta diminuiu linearmente a cobertura de gordura durante o período de crescimento, mas tendeu a aumentar linearmente a área de olho de lombo (AOL) durante o período de terminação de bovinos em confinamento, melhorando a qualidade da carcaça e tendendo a aumentar a porção de carne comercializável, possuindo potencial para melhorar a eficiência alimentar e a qualidade da carne. Trabalhos anteriores sugeriram que ligninas purificadas também possuem propriedades antioxidantes (AYYACHAMY et al., 2013; DONG et al., 2011; UGARTONDO; MITJANS; VINARDELL, 2008).

De acordo com Catignani e Carter (1982), os fragmentos fenólicos da lignina Kraft, obtidos como subproduto durante extração de celulose no processo de fabricação de papel por hidrólise alcalina de madeira, são tão eficazes quanto a vitamina $\mathrm{E}$ como antioxidante em humanos.

Diante do exposto, a premissa deste estudo foi avaliar os efeitos da lignina Kraft como aditivo comparado à monensina, ionóforo conhecido, e ao Selênio e vitamina E, antioxidantes conhecidos, sobre o desempenho, saúde ruminal, controle do estresse oxidativo e características da carcaça e da qualidade da carne de cordeiros alimentados com dietas com elevada proporção de concentrado. 


\section{$5.1 \quad$ Local}

O experimento foi realizado no anexo do Laboratório de Avaliação Animal e Qualidade da Carne presente no Departamento de Zootecnia da Faculdade de Zootecnia e Engenharia de Alimentos em Pirassununga - SP, em área sob as coordenadas $21^{\circ} 59^{\prime}$ de latitude sul e $47^{\circ} 26^{\prime}$ de longitude oeste (W. Gr) e altitude média de 635 metros. Segundo a classificação de Koppen, o clima da região é classificado como Cwa, mesotérmico com chuvas predominantemente no verão, apresentando inverno seco e verões quentes, com temperatura média anual de $22^{\circ} \mathrm{C}$ e pluviosidade média anual próxima a $1363 \mathrm{~mm}$.

\subsection{Animais, instalações e tratamentos}

Foram utilizados 32 cordeiros machos, não castrados, cruzados da raça Dorper x Santa Inês, recém-desmamados, com peso corporal médio inicial e idade de $23 \pm 6,3 \mathrm{~kg}$ e 60 dias, respectivamente. Os animais foram mantidos em galpão coberto, em gaiolas individuais $(2 \times 1,25 \mathrm{~m})$ com piso ripado e água a vontade e foram alimentados ad libitum às $07 \mathrm{~h} 00$ (80\%) e às 17h00 (20\%).

Figura 1 - Animais nas baias de confinamento

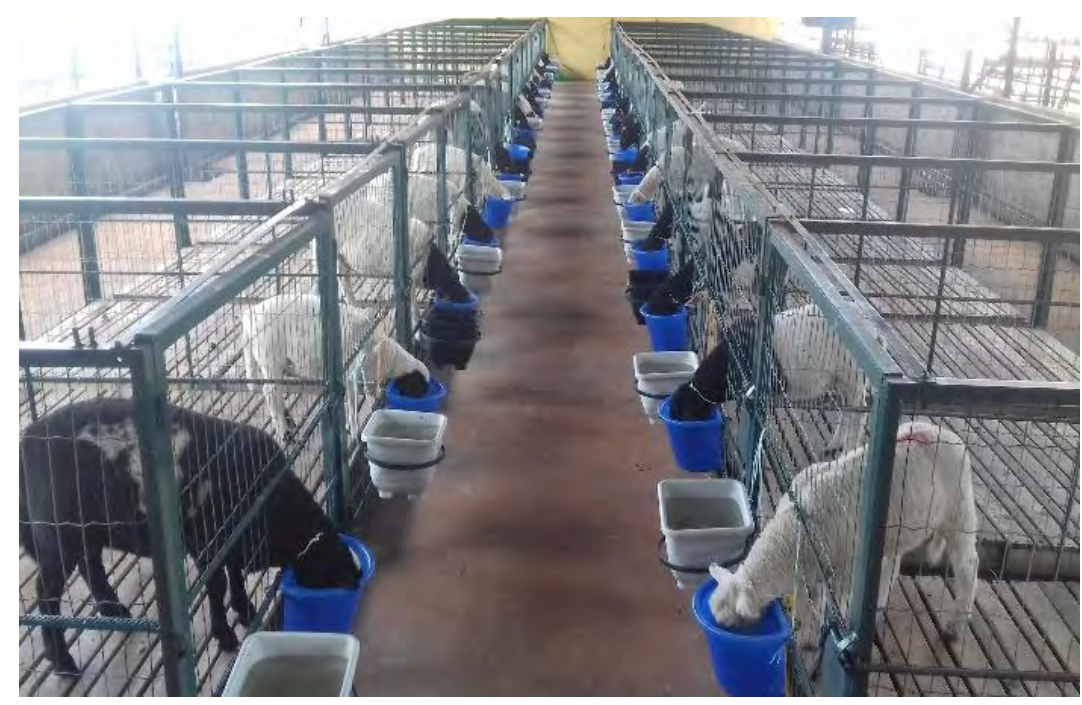

Fonte: autoria própria 
A dieta foi composta por $10 \%$ de volumoso (feno de capim Cynodon sp.) e $90 \%$ de concentrado a base de milho grão, contendo farelo de soja, ureia e minerais, diferindo apenas na inclusão ou não dos aditivos. A mistura foi feita em misturador tipo horizontal com hélices helicoidais, com duração de 10 minutos por batida.

Utilizou-se o delineamento em blocos casualizados, utilizando-se 0 peso corporal inicial como critério de blocagem, no qual os 32 animais foram distribuídos em três blocos com quatro tratamentos, onde cada animal (baia) foi considerado uma unidade experimental, sendo oito repetições por tratamento:

1) Tratamento CTL: sem aditivos.

2) Tratamento MON: monensina (15 mg/kg MS).

3) Tratamento LKR: lignina Kraft (12,5 g/kg MS).

4) Tratamento SeE: selênio (Se) e vitamina E (0,33 mg/kg e $100 \mathrm{Ul} / \mathrm{kg}$, respectivamente). O requerimento de Se para ovinos desta categoria é de 0,26 mg/kg MS (NRC, 2007).

A lignina purificada utilizada neste experimento foi extraída da madeira de Eucalyptus urograndis, resultante do processo Kraft de produção de celulose de eucalipto.

O produto foi composto por $97 \%$ de lignina (rica em compostos fenólicos como guaiacol e siringol). O restante da composição corresponde a cerca de $3 \%$ de cinzas e carboidratos (xilose e glicose).

Os animais foram adaptados às instalações e ao manejo durante cinco dias. A quantidade de alimento ofertada para o primeiro dia de confinamento foi de $4 \%$ do peso vivo em matéria seca da dieta e o nível de oferta foi ajustado para manter consumo ad libitum (10\% sobras).

A sobra dos cochos foi retirada diariamente durante os primeiros dias de confinamento, sendo que após este período as sobras passaram a ser retiradas três vezes por semana antes do trato da manhã, fazendo-se a média do consumo para cada baia.

A quantidade de alimento fornecido e as sobras foram registradas diariamente. Amostras foram recolhidas e devidamente acondicionadas em sacos plásticos para análise de matéria seca, proteína bruta, nitrogênio não 
proteico, fibra em detergente ácido e fibra em detergente neutro, segundo os padrões da AOAC - Association of Official Agricultural Chemists (1995). Os nutrientes digestíveis totais foram estimados segundo Weiss, Conrad e Pierre (1992). Os teores de Se dos tratamentos CTL, LKR, MON e SeE foram analizados por fluorimetria (OLSON; PALMER; CARY, 1975), com concentrações de $0,13,0,17,0,12$ e $0,29 \mathrm{mg} / \mathrm{kg} \mathrm{MS}$, respectivamente.

A ingestão média diária de matéria seca (IMS) foi calculada através da quantidade de MS da dieta fornecida menos a quantidade de MS das sobras. A eficiência alimentar (EA) dos animais foi obtida como a razão entre ganho de peso e IMS. Para o monitoramento do ganho médio diário (GMD), os animais foram pesados a cada 14 dias pela manhã, sem jejum prévio para evitar possível acidose. Antes de iniciar o período experimental, fezes foram coletadas para a análise preventiva de ovos por grama de fezes (OPG). A composição química e os nutrientes da dieta utilizada estão presentes na tabela 1. 


\begin{tabular}{|c|c|c|c|c|}
\hline \multirow[b]{2}{*}{ Ingredientes (\%) } & \multicolumn{4}{|c|}{ Tratamentos } \\
\hline & CTL & LKR & MON & SeE \\
\hline Milho grão moído & 72,80 & 71,55 & 72,79 & 72,73 \\
\hline Farelo de soja & 14,00 & 14,00 & 14,00 & 14,00 \\
\hline Feno coastcross & 10,00 & 10,00 & 10,00 & 10,00 \\
\hline Calcáreo calcítico & 1,50 & 1,50 & 1,50 & 1,50 \\
\hline Suplemento mineral ${ }^{1}$ & 0,70 & 0,70 & 0,70 & 0,70 \\
\hline Uréia & 0,50 & 0,50 & 0,50 & 0,50 \\
\hline Cloreto de amônia & 0,50 & 0,50 & 0,50 & 0,50 \\
\hline Lignina $\mathrm{Kraft}^{2}$ & - & 1,25 & - & - \\
\hline Rumenpac ${ }^{3}$ & - & - & 0,0075 & - \\
\hline Suplemento Selênio + Vitamina $E^{4}$ & - & - & - & 0,0700 \\
\hline TOTAL & 100,00 & 100,00 & 100,00 & 100,00 \\
\hline \multicolumn{5}{|l|}{ NUTRIENTES \% } \\
\hline Nutrientes digestíveis totais & 80,40 & 79,30 & 80,40 & 80,34 \\
\hline Proteína bruta & 18,08 & 18,06 & 17,83 & 18,14 \\
\hline Proteína degradável no rúmen & 10,15 & 10,14 & 10,01 & 10,18 \\
\hline Fibra em detergente neutro & 20,27 & 22,67 & 18,84 & 18,77 \\
\hline Fibra em detergente neutro efetiva & 9,72 & 9,72 & 9,72 & 9,72 \\
\hline Fibra em detergente ácido & 13,23 & 12,33 & 11,43 & 11,07 \\
\hline $\mathrm{N}$ ligado à fibra em detergente neutro & 0,26 & 0,31 & 0,26 & 0,25 \\
\hline N ligado à fibra em detergente ácido & 0,36 & 0,35 & 0,37 & 0,32 \\
\hline Lignina em detergente ácido & 2,48 & 2,77 & 1,65 & 1,69 \\
\hline $\mathrm{Ca}$ & 0,80 & 0,61 & 0,74 & 0,74 \\
\hline $\mathrm{P}$ & 0,28 & 0,29 & 0,27 & 0,27 \\
\hline Se, $\mathrm{mg} / \mathrm{kg}$ & 0,13 & 0,17 & 0,12 & 0,29 \\
\hline
\end{tabular}

${ }^{1}$ Coplasal Ovinos ${ }^{\circledR}$ (Coplacana) Cálcio 155g, Fósforo 83g, Magnésio - 10g , Enxofre - 35g, Sódio - 120g, Cobre - 756mg, Zinco $-2.800 \mathrm{mg}$, lodo $-56 \mathrm{mg}$, Cobalto - 44mg, Selênio $14 \mathrm{mg}$, Flúor - 250mg.

${ }^{2}$ Suzano Papel e Celulose S.A

${ }^{3}$ Rumenpac ${ }^{\oplus}$ - Mcassab (Monensina mínimo $200 \mathrm{mg} / \mathrm{kg}$ )

${ }^{4}$ E-S-E Super ${ }^{\circledR}$ - Vetnil (150mg Selênio/ 150000 UI Vit.E/kg produto)

\subsection{Análises bioquímicas}

\subsubsection{Estresse oxidativo}

Para análises de estresse oxidativo foram realizadas três colheitas de sangue (antes de iniciar os tratamentos, aos 29 e aos 54 dias de confinamento), para avaliar a atividade enzimática e 0 balanço oxidante/antioxidante. Os animais foram contidos nas baias para minimizar a 
movimentação e o estresse causado durante o manejo, e as amostras de sangue foram coletadas via punção venosa intrajugular.

As coletas foram realizadas com tubos Vacutainer®, sendo um com EDTA para separação de plasma e outro sem para separação de soro. Avaliouse os níveis de glutationa peroxidase (GSH-Px), superóxido dismutase (SOD), catalase e peroxidases no plasma, devido a sua maior capacidade de conservação de metabólitos pela não ocorrência de uma cascata de coagulação, permitindo que as enzimas não sejam retidas no agregado plaquetário, promovendo melhor homogeneidade dos metabólitos em detrimento do soro. Os níveis de peróxido de hidrogênio $\left(\mathrm{H}_{2} \mathrm{O}_{2}\right)$ foram avaliados no soro devido à especificação do kit comercial de análise.

As avaliações foram feitas através dos kits comerciais (BioAssay Systems $($ ) $)$ específicos para cada metabólito que disponibilizaram a mensuração da atividade enzimática no plasma ou soro sanguíneo através da preparação da reação química e leitura em espectrofotômetro (Multiskan GO Thermo Scientific $($ )). O valor da atividade enzimática de cada amostra foi calculado a partir dos valores de absorbância obtidos após a leitura. A metodologia adotada para a utilização de cada kit e para os cálculos foi seguida de acordo com as especificações do fabricante.

\subsection{Abate, mensurações na carcaça e coleta de amostras}

Após 55 dias de confinamento, os cordeiros foram transportados ao matadouro-escola da Faculdade de Zootecnia e Engenharia de Alimentos em caminhão próprio para ovinos, com distância de 200 m do galpão experimental. O abate foi realizado seguindo os procedimentos humanitários estabelecidos pela legislação brasileira. Os animais foram insensibilizados através do atordoamento com pistola de dardo cativo penetrante e a sangria foi feita pelo corte da veia jugular e da artéria carótida. As carcaças foram então esfoladas, evisceradas, lavadas, identificadas e pesadas para determinação do peso de carcaça quente (PCQ) (Figuras 2 e 3). 


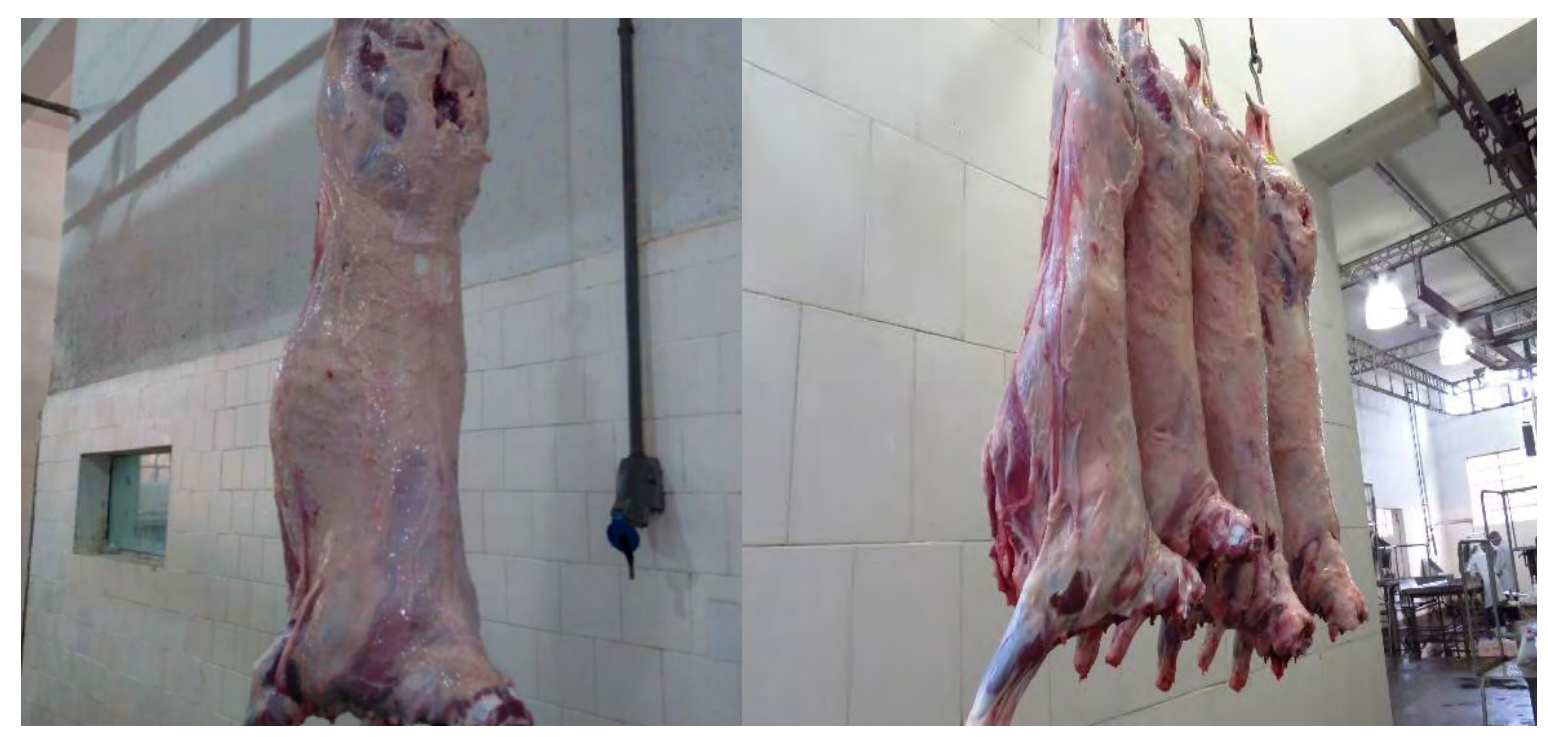

Figura 2 - Pesagem individual das carcaças dos animais após o abate. Fonte: Autoria própria.

Figura 3 - Carcaças dos animais após o abate. Fonte: Autoria própria.

Após uma hora, mensurou-se o pH e a temperatura das carcaças (TC) no músculo Longissimus na altura da $12^{\circ}$ costela, utilizando termômetro e peagâmetro digitais com probe de penetração (modelo HI8314, Hanna Instruments) e armazenadas em câmara fria $\left(0-2^{\circ} \mathrm{C}\right)$ por 24 horas. Após este período, as carcaças foram novamente pesadas para a determinação do peso de carcaça fria (PCF), $\mathrm{pH}$ e $\mathrm{T} \stackrel{\circ}{ } \mathrm{C}$, medidos no mesmo local. $\mathrm{O}$ rendimento de carcaça fria $(\mathrm{RCF})$ foi calculado através da razão entre o peso da carcaça fria e o peso vivo final do animal, multiplicada por 100.

As carcaças foram divididas ao meio, e a meia-carcaça esquerda foi seccionada entre a $12^{\mathrm{a}}$ e a $13^{\mathrm{a}}$ costela para a mensuração da área de olho de lombo (AOL) com uma grade reticulada transparente específica de $1 \mathrm{~cm}^{2}$ e a espessura de gordura subcutânea (EGS), utilizando uma régua com graduação milimétrica.

\subsubsection{Cor, perdas por cocção, força de cisalhamento e tempo de prateleira}

A analise de cor foi feita 30 minutos após a exposição ao oxigênio pela secção do músculo Longissimus entre a $12^{\circ}$ e $13^{\circ}$ costelas, através de um espectrofotômetro portátil (modelo CM2500d Konica Minolta Brasil), utilizando 
um iluminante $\mathrm{D} 65$, com ângulo de observação de $10^{\circ}$ e abertura do obturador de $10 \mathrm{~mm}$, previamente calibrado com os padrões preto e branco, operando no sistema CIE L*a*b (CIE, 1986) (em que L* é o croma associado à luminosidade ( $L^{*}=0$ preto, 100 branco), $a^{*}$ é o croma que varia do verde (-) ao vermelho $(+)$, e $b^{*}$, que varia do azul (-) ao amarelo). A avaliação da cor foi realizada em três pontos distintos da amostra e tomando-se como valor da cor a média das três leituras.

Para a análise da força de cisalhamento (maciez - FC) e perdas por cocção (PPC), três bifes de aproximadamente $2,5 \mathrm{~cm}$ de espessura foram removidos do músculo Longissimus entre a $12^{\mathrm{a}}$ e a $13^{\mathrm{a}}$ costela, embalados a vácuo e imediatamente congelados para posterior análise. No dia anterior à avaliação da maciez, as amostras foram descongeladas em geladeira $\left(2-5^{\circ} \mathrm{C}\right)$, retiradas da embalagem e pesadas individualmente para determinação do peso inicial.

Em seguida, um termômetro foi inserido no centro geométrico de cada bife e as amostras foram aquecidas em um forno elétrico industrial (modelo F130 / L, Fornos Elétricos Flecha de Ouro Ind. E Com. Ltda., São Paulo, Brasil) a $170{ }^{\circ} \mathrm{C}$ até a temperatura interna atingir $40^{\circ} \mathrm{C}$. Os bifes foram então virados e cozidos até atingir uma temperatura interna de $71^{\circ} \mathrm{C}$. As amostras foram resfriadas à temperatura ambiente $\left(22^{\circ} \mathrm{C}\right)$, novamente pesadas, envoltas em filme plástico e armazenadas no refrigerador $\left(4-6{ }^{\circ} \mathrm{C}\right)$ até o dia seguinte. $\mathrm{A}$ diferença do peso das amostras antes e após o cozimento foi utilizada para determinar percentual de perdas por cocção.

Foram retirados quatro a seis cilindros $(1,27 \mathrm{~cm}$ de diâmetro) de cada amostra paralelamente à orientação da fibra muscular e cisalhados em um texturômetro (TMS-PRO - Food Technology Corporation, Sterling, EUA) para a determinação da força de cisalhamento. A força de cisalhamento de cada amostra foi obtida como a média das repetições e é expressa em Newton (N) (AMERICAN MEAT SCIENCE ASSOCIATION - AMSA, 1995).

Para análise do comportamento da cor e da oxidação lipídica durante a exposição no display (tempo de prateleira), bifes com aproximadamente $1,5 \mathrm{~cm}$ de espessura foram retirados do músculo Longissimus entre as $12^{\underline{a}}$ e $13^{\mathrm{a}}$ costelas e acomodados em bandejas de isopor com papel absorvente e envoltos em filme de PVC, separadas por tratamento e colocadas 
aleatoriamente em painel expositor refrigerado a uma temperatura de $4^{\circ} \mathrm{C}$ e incidência luminosa de 1.000 lux, onde permaneceram por cinco dias, sendo coletados nos tempos 1, 3 e 5 (dias) As amostras foram analisadas para substâncias reativas ao ácido tiobarbitúrico (TBARS) antes e após a exposição nos dias 1,3 e 5 .

5.4.2 Oxidação lipídica pela análise de substâncias reativas ao ácido tiobarbitúrico (TBARS)

Foram pesadas $5 \mathrm{~g}$ de amostra dos bifes expostos no painel expositor refrigerado, que posteriormente foram trituradas e homogeneizadas para análise de substâncias reativas ao ácido 2-tiobarbitúrico (TBARS), conforme metodologia proposta por Vyncke et al. (1975). Preparou-se uma curva com cinco pontos, utilizando-se uma solução de tetraetoxipropano (TEP) de concentração conhecida. As leituras das absorbâncias foram realizadas em 530 e 638 nm em espectrofotômetro (Multiskan GO - Thermo Scientific®). Para obter-se a concentração de malondialdeído nas amostras, utilizou-se a equação fornecida pela curva. Os resultados foram expressos em $\mu \mathrm{g}$ malondialdeído/kg carne.

\subsubsection{Análise de ruminite e parâmetros de morfologia ruminal}

Durante a evisceração, efetuou-se uma incisão através de corte único na região mediana do abdômen, iniciando-se na região do púbis em sentido ao esterno, para obtenção do composto rúmen, retículo, omaso e abomaso. Para avaliar o índice de rumenite, após a obtenção do composto, o rúmen foi isolado dos outros compartimentos, aberto, lavado em água corrente e examinado. As papilas ruminais foram classificadas visualmente, de acordo com a incidência de lesões, em uma escala de escore de 0 a 10 (BIGHAM; McMANAUS, 1975), em que cada ponto de escore representa $10 \%$ do rúmen comprometido, considerando incidência de rumenite qualquer classificação acima de zero. A avaliação é visual e subjetiva, portanto foi realizada por uma pessoa treinada.

Posteriormente, identificou-se o saco cranial do rúmen, de onde foram amostrados fragmentos de cerca de $10 \mathrm{~cm}^{2}$ e acondicionados em solução 
tampão fosfato e armazenados a $-4^{\circ} \mathrm{C}$ para conservação das células, para avaliação morfológica das papilas. Para a determinação do número de papilas por $\mathrm{cm}^{2}$, as papilas foram contadas em um fragmento de $1 \mathrm{~cm}^{2}$, por três avaliadores, determinando-se como o número de papilas a média das três contagens. Posteriormente foram seccionados da base dos fragmentos doze papilas, para mensuração da área média das papilas, percentual de área papilar e superfície total de absorção por $\mathrm{cm}^{2}$ de parede. A estimação do fragmento e das doze papilas para mensuração das variáveis foi realizada através do programa de análise de imagens UTHSCSA Image Tool (RESENDE JÚNIOR et al., 2006).

\subsection{Análise dos resultados}

Para a análise dos dados foi utilizado um delineamento em blocos casualizados (peso inicial; $n=4$ ), com 32 animais distribuídos em quatro tratamentos, totalizando oito repetições por tratamento. Cada animal (baia) foi considerado uma unidade experimental. Para a análise do efeito dos tratamentos sobre as características avaliadas, o tratamento foi considerado como efeito fixo e o bloco como efeito aleatório.

Os resultados das avaliações de vida de prateleira $\left(L^{*}, a^{*}, b^{*}\right.$ e TBARS), assim como as análises enzimáticas foram analisadas como medidas repetidas no tempo, considerando-se o tratamento, dias na prateleira e a interação como efeitos fixos, enquanto que 0 animal e o bloco foram considerados como efeitos aleatórios. As estruturas de covariância foram modeladas e a que apresentou melhor ajuste (estrutura composta - CS) foi utilizada.

Os resultados das avaliações de escore de ruminite foram normalizados pelo teste de Shapiro-Wilk para corrigir as variâncias e analisados pelo procedimento MIXED.

Os dados obtidos foram avaliados por análise de variância, utilizando 0 procedimento MIXED do software SAS 9.3 (SAS Institute Inc., Cary, NC, EUA). 


\section{RESULTADOS}

\subsection{Desempenho}

Não foi observado efeito dos tratamentos para nenhuma das características de desempenho avaliadas (Tabela 2).

O ganho de peso médio diário variou de 0,320 a 0,340 kg/dia e a ingestão média de alimento foi de $1,21 \mathrm{~kg} / \mathrm{dia}$.

Tabela 2 - Características de desempenho de cordeiros alimentados com dietas de alto concentrado com diferentes aditivos

\begin{tabular}{|c|c|c|c|c|c|c|}
\hline \multirow{2}{*}{ Variável } & \multicolumn{4}{|c|}{ Tratamentos } & \multirow{2}{*}{ EPM } & \multirow{2}{*}{$P$} \\
\hline & CTL & LKR & MON & $\mathrm{SeE}$ & & \\
\hline Peso inicial, kg & 22,86 & 22,90 & 23,26 & 22,90 & 2,000 & 0,975 \\
\hline Peso final, $\mathrm{kg}$ & 41,16 & 40,55 & 40,77 & 40,80 & 3,540 & 0,989 \\
\hline GMD, kg/dia & 0,34 & 0,33 & 0,32 & 0,33 & 0,038 & 0,878 \\
\hline IMS, kg/dia & 1,26 & 1,26 & 1,18 & 1,16 & 0,191 & 0,606 \\
\hline$E A, g / k g ~ M S$ & 0,29 & 0,26 & 0,28 & 0,29 & 0,032 & 0,217 \\
\hline
\end{tabular}

Assim como observado para as características de desempenho, também não foi verificado efeito dos tratamentos sobre nenhuma das características de carcaça e qualidade da carne dos animais (Tabela 3). 
Tabela 3 - Características de carcaça e qualidade da carne cordeiros alimentados com dietas de alto concentrado com diferentes aditivos

\begin{tabular}{|c|c|c|c|c|c|c|}
\hline \multirow{2}{*}{ Variável } & \multicolumn{4}{|c|}{ Tratamentos } & \multirow{2}{*}{ EPM } & \multirow{2}{*}{$P$} \\
\hline & CTL & LKR & MON & $\overline{\mathrm{SeE}}$ & & \\
\hline $\mathrm{PCQ}, \mathrm{kg}$ & 20,00 & 19,45 & 20,08 & 19,48 & 2,080 & 0,891 \\
\hline RC quente, $\%$ & 48,41 & 47,94 & 49,06 & 47,67 & 1,620 & 0,360 \\
\hline $\mathrm{pH} 1 \mathrm{~h}$ & 6,50 & 6,26 & 6,34 & 6,41 & 0,190 & 0,104 \\
\hline $\mathrm{TC} 1 \mathrm{~h},{ }^{\circ} \mathrm{C}$ & 31,40 & 32,11 & 30,93 & 31,62 & 1,540 & 0,506 \\
\hline$P C F, k g$ & 19,15 & 18,95 & 19,61 & 18,92 & 2,040 & 0,899 \\
\hline $\mathrm{RC}$ fria, $\%$ & 46,24 & 46,71 & 48,06 & 46,28 & 2,270 & 0,360 \\
\hline $\mathrm{pH} 24 \mathrm{~h}$ & 5,47 & 5,50 & 5,47 & 5,48 & 0,150 & 0,983 \\
\hline $\mathrm{TC} 24 \mathrm{~h},{ }^{\circ} \mathrm{C}$ & 9,33 & 9,21 & 9,67 & 9,63 & 1,060 & 0,780 \\
\hline \multicolumn{7}{|l|}{ Cor } \\
\hline$L^{*}$ & 30,50 & 28,50 & 29,00 & 29,75 & 2,970 & 0,566 \\
\hline$a^{*}$ & 13,68 & 13,18 & 13,62 & 13,86 & 2,070 & 0,926 \\
\hline$b^{*}$ & 16,54 & 16,07 & 16,18 & 16,89 & 1,730 & 0,779 \\
\hline $\mathrm{AOL}, \mathrm{cm}^{2}$ & 15,75 & 14,62 & 17,37 & 16,50 & 3,000 & 0,329 \\
\hline $\mathrm{EGS}, \mathrm{mm}$ & 2,97 & 2,56 & 2,27 & 2,56 & 0,630 & 0,199 \\
\hline PPC, \% & 30,36 & 24,27 & 31,40 & 28,85 & 5,710 & 0,090 \\
\hline$F C, N$ & 33,73 & 33,46 & 39,92 & 28,92 & 8.580 & 0,109 \\
\hline
\end{tabular}

Médias seguidas da mesma letra não possuem diferença significativa, médias seguidas de letras diferentes possuem diferença significativa.

PCQ - Peso de carcaça quente; RC - Rendimento de carcaça; TC Temperatura de carcaça; PCF - Peso de carcaça fria; AOL - Área de olho de lombo; EGS - Espessura de gordura subcutânea; PPC - Perdas por cocção; FC - Força de cisalhamento.

\subsection{Características ruminais}

Maior incidência de lesões na parede ruminal foi observada nos animais tratados com lignina ( $P=0,030$; Tabela 4$)$, onde 0 tratamento LKR apresentou quatro animais (50\%) com lesões nos graus 3 ou superior, sendo que destes, 2 (25\% do total) apresentaram lesão de grau 5 (50\% do rúmen comprometido). 
Tabela 4 - Incidência de ruminite e parâmetros de morfologia ruminal de cordeiros alimentados com dietas de alto concentrado com diferentes aditivos

\begin{tabular}{lccccccc}
\hline \multirow{2}{*}{ Variável } & \multicolumn{5}{c}{ Tratamentos } & \multirow{2}{*}{ EPM } & P \\
\cline { 2 - 5 } & CTL & LKR & MON & SeE & & \\
\hline Ruminite & $0,75 \mathrm{~B}$ & $2,25 \mathrm{~A}$ & $0,38 \mathrm{~B}$ & $0,75 \mathrm{~B}$ & 0,450 & 0,030 \\
Área média de papilas, $\mathrm{cm}^{2}$ & 0,21 & 0,17 & 0,19 & 0,17 & 0,070 & 0,703 \\
Área absorção, $\mathrm{cm}^{2}$ de parede & 11,75 & 11,68 & 12,69 & 12,58 & 4,270 & 0,945 \\
Área total da superfície & 90,82 & 90,58 & 92,78 & 93,03 & 3,580 & 0,401 \\
absortiva, \% & $50,47 \mathrm{~B}$ & $66,18 \mathrm{~A}$ & $63,02 \mathrm{AB}$ & $68,5 \mathrm{~A}$ & 12,760 & 0,042 \\
\hline Número médio de papilas $/ \mathrm{cm}^{2}$ & &
\end{tabular}

Médias seguidas da mesma letra não possuem diferença significativa, médias seguidas de letras diferentes possuem diferença significativa.

Apesar da maior incidência de lesões aparentes no tratamento LKR, não houve diferença entre os tratamentos para a área média de papilas, área de absorção e área total de superfície absortiva. Porém, foi observada uma diferença no número médio de papilas $/ \mathrm{cm}^{2}$, onde o tratamento $\mathrm{CTL}$ apresentou menor valor $(P=0,042)$ em comparação com os demais.

\subsection{Vida de prateleira}

Não houve interação significativa entre os tratamentos e o tempo de prateleira para os valores de $\mathrm{a}^{*} \mathrm{e} \mathrm{b}^{*}$ da cor, tampouco efeito dos tratamentos (Tabela 5). Por outro lado, foi observada uma interação para os valores de $L^{*}$ durante o tempo de exposição no display ( $P=0,001$; Figura 4), em que 0 tratamento MON apresentou os menores valores de $L^{*}$ no primeiro dia de exposição, indicando carne mais escura, que tenderam a subir nos dias 3 e 5 , havendo um clareamento da carne durante a exposição. 


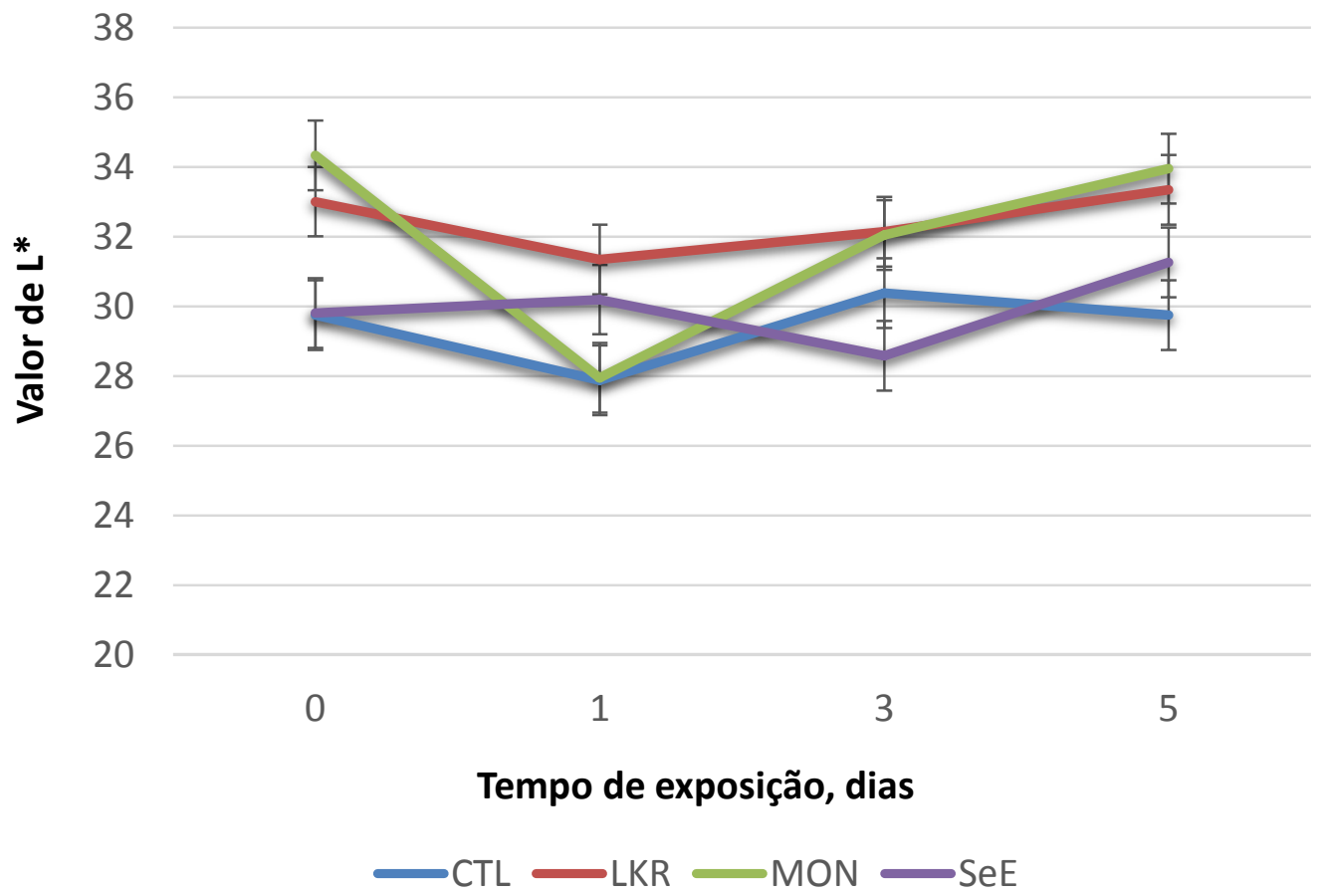

Figura 4 - Valores médios de cor $L^{*}$, em função dos tratamentos e dias na prateleira.

Houve uma interação entre o tempo e os tratamentos para os valores de TBARS (Figura 5). Conforme o esperado, não houve diferença entre os tratamentos para os valores de TBARS na avaliação inicial (24h após o abate). Após esse período (1, 3 e 5 dias na prateleira), o tratamento SeE apresentou os menores valores de oxidação lipídica em comparação aos tratamentos CTL, LKR e MON ( $P=0,005 ;$ Tabela 5$)$. Além disso, exibiu menores valores em todos os tempos de avaliação $(P<0,0001)$.
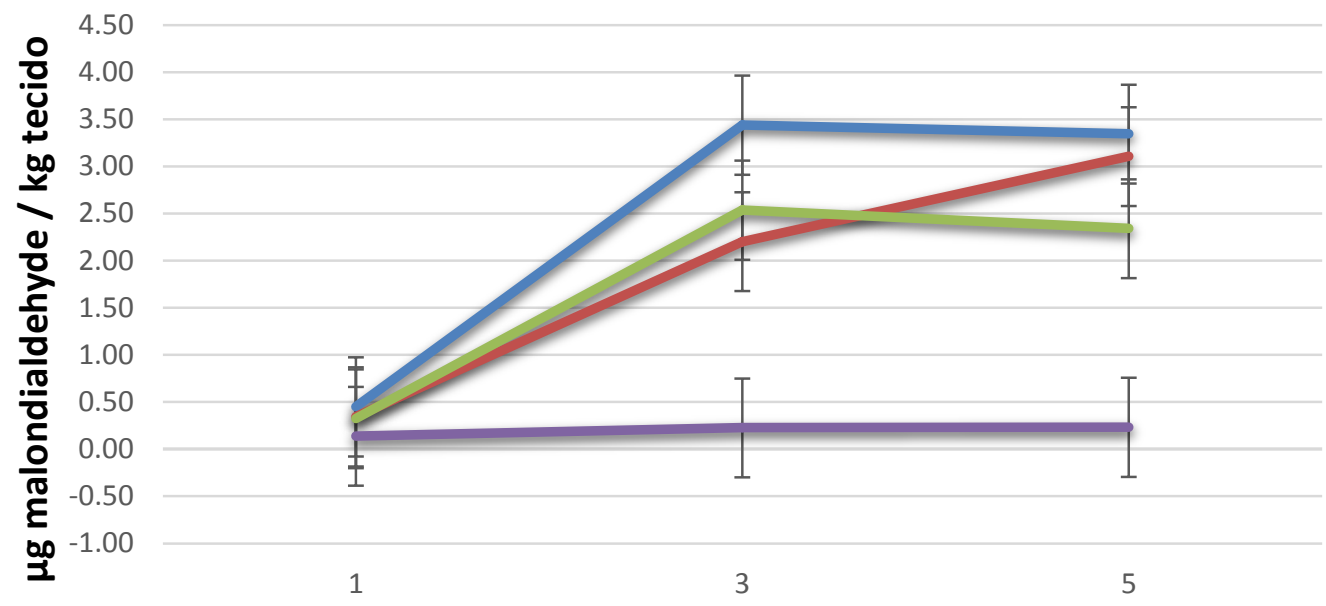

Tempo de exposição, dias

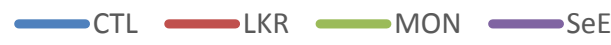

Figura 5 - Valores médios de substâncias reativas ao ácido tiobarbitúrico (TBARS), em função dos tratamentos e dias na prateleira. 


\subsection{Atividade enzimática}

Não foi observada interação entre o tempo de confinamento e os tratamentos para os níveis plasmáticos de Glutationa peroxidase (GSH-Px) e Superóxido dismutase (SOD), ou séricos de peróxido de hidrogênio $\left(\mathrm{H}_{2} \mathrm{O}_{2}\right)$ (Tabela 6). No entanto, houve efeito de tempo sobre a atividade enzimática de SOD ( $P=0,001)$, que aumentou durante o tempo de avaliação, e para os níveis séricos de $\mathrm{H}_{2} \mathrm{O}_{2} \quad(\mathrm{P}<0,0001)$, apresentando atividade reduzida durante $\mathrm{O}$ período avaliado.

Foi observada interação entre o tempo de confinamento e os tratamentos para a atividade enzimática de catalase $(P=0,035$; Figura 6$)$ e para as peroxidases $(P=0,052$; Figura 7$)$. $O$ tratamento $M O N$ mostrou decréscimo na atividade durante o período de avaliação, apresentando menor atividade enzimática de catalase aos 29 dias de confinamento em comparação ao CTL $(P=0,030)$. Aos 54 dias, o tratamento $\mathrm{MON}$ apresentou menor atividade comparado ao SeE $(P=0,042)$.

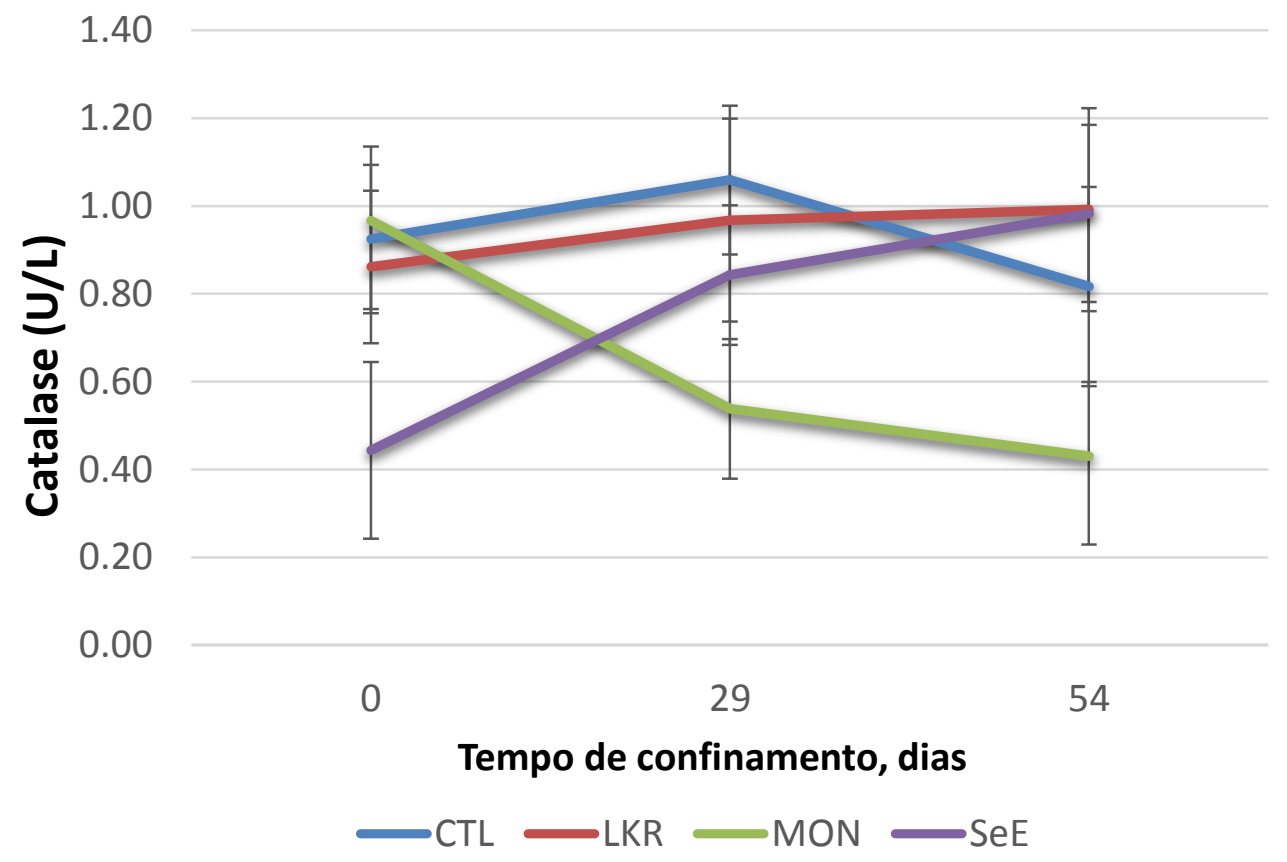

Figura 6 - Atividade enzimática de Catalase no plasma, em função dos tratamentos e tempo de confinamento. 
Com relação aos níveis de peroxidases, não houve diferença entre os tratamentos na avaliação realizada no início do confinamento. No entanto, aos 29 dias, foi observada uma maior atividade de peroxidases no tratamento LKR em relação aos tratamentos $\mathrm{MON}(P=0,005)$ e $\operatorname{SeE}(P=0,015)$. Os demais tratamentos não diferiram entre si.

Por outro lado, na avaliação final (54 dias), observou-se um aumento nos níveis de peroxidases no tratamento $\mathrm{MON}$, com maiores níveis que os tratamentos CTL $(P=0,047)$ e LKR $(P=0,038)$, sendo que os demais tratamentos não diferiram entre si.

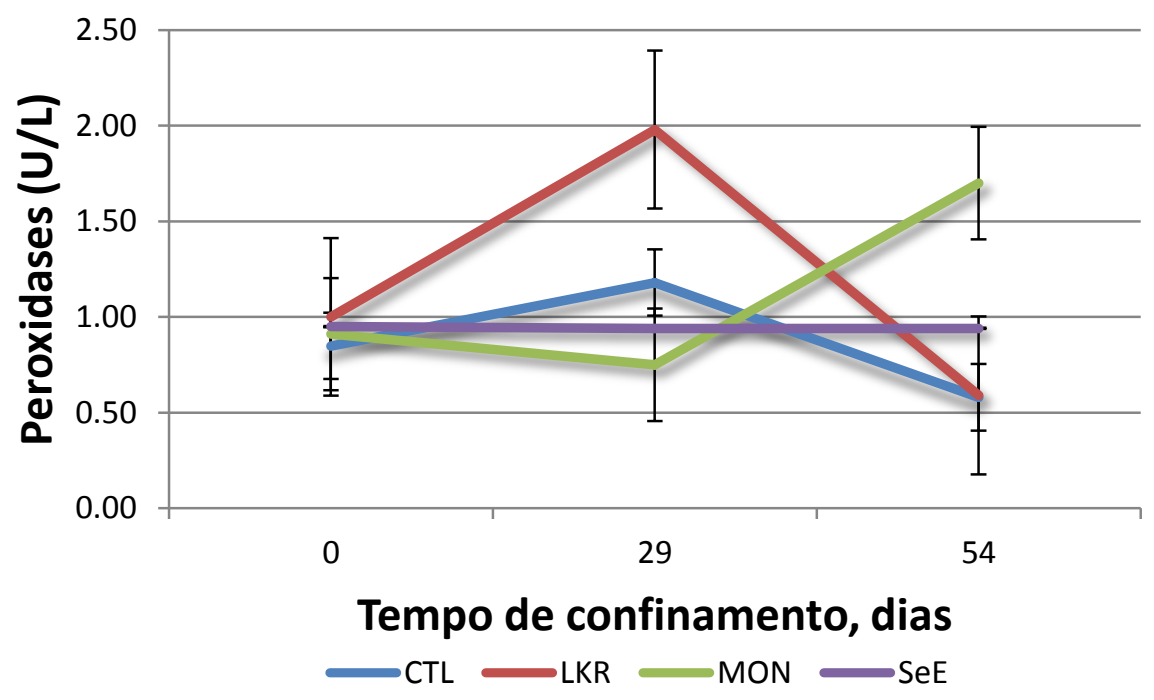

Figura 7 - Atividade enzimática das peroxidases no plasma, em função dos tratamentos e tempo de confinamento. 
Tabela 5 - Comportamento da cor $\left(L^{*}, a^{*}\right.$ e b*) e peroxidação lipídica da carne de cordeiros alimentados com dietas de alto concentrado com diferentes aditivos durante o tempo exposição da prateleira

\begin{tabular}{|c|c|c|c|c|c|c|c|c|c|c|c|c|c|}
\hline \multirow{2}{*}{ Variável } & \multicolumn{4}{|c|}{ Tratamentos } & \multirow{2}{*}{ EPM } & \multicolumn{4}{|c|}{ Dias na prateleira } & \multirow{2}{*}{ EPM } & \multicolumn{3}{|c|}{$\mathrm{P}$} \\
\hline & CTL & LKR & MON & SeE & & 0 & 1 & 3 & 5 & & Trat & Tempo & $\begin{array}{l}\text { Trat }^{*} \\
\text { Tempo }\end{array}$ \\
\hline$L^{*}$ & 31,70 & 29,30 & 30,80 & 32,10 & 1,09 & 29,40 & 32,50 & 32,10 & 30,00 & 0,93 & 0,063 & $<0,0001$ & 0,001 \\
\hline$a^{*}$ & 13,60 & 13,40 & 13,80 & 13,40 & 0,55 & 13,06 & 13,10 & 12,90 & 14,70 & 0,47 & 0,947 & 0,0002 & 0,076 \\
\hline$b^{*}$ & 16,00 & 16,00 & 16,80 & 16,60 & 0,42 & 16,40 & 18,60 & 14,10 & 16,30 & 0,32 & 0,400 & $<0,0001$ & 0,160 \\
\hline TBARS & 2,41 & 1,73 & 1,88 & 0,20 & 0,40 & - & 0,31 & 2,10 & 2,26 & 0,27 & 0,001 & $<0,0001$ & 0,005 \\
\hline
\end{tabular}

Tabela 6. Parâmetros de estresse oxidativo no plasma e soro de cordeiros alimentados com dietas de alto concentrado com diferentes aditivos

\begin{tabular}{|c|c|c|c|c|c|c|c|c|c|c|c|c|}
\hline \multirow[b]{2}{*}{ Variável } & \multicolumn{4}{|c|}{ Tratamentos } & \multirow[b]{2}{*}{ EPM } & \multicolumn{3}{|c|}{ Dias } & \multirow[b]{2}{*}{ EPM } & \multicolumn{3}{|c|}{$P$} \\
\hline & CTL & LKR & MON & SeE & & 0 & 28 & 55 & & Trat & Tempo & $\begin{array}{l}\text { Trat }^{*} \\
\text { Tempo }\end{array}$ \\
\hline GSH-px & 84,30 & 74,70 & 86,00 & 96,70 & 12,20 & 77,70 & 93,80 & 10,40 & 10,30 & 0,647 & 0,532 & 0,398 \\
\hline Catalase & 0,93 & 0,94 & 0,64 & 0,76 & 0,137 & 0,80 & 0,85 & 0,81 & 0,950 & 0,346 & 0,858 & 0,035 \\
\hline $\mathrm{H}_{2} \mathrm{O}_{2}$ & 160,10 & 179,80 & 195,50 & 201,80 & 18,63 & 255,00 & 164,40 & 133,50 & 17,44 & 0,456 & $<0,0001$ & 0,907 \\
\hline Peroxidases & 0,87 & 1,21 & 1,13 & 0,95 & 0,175 & 0,94 & 1,22 & 0,96 & 0,157 & 0,506 & 0,364 & 0,052 \\
\hline SOD & 5,00 & 3,60 & 3,30 & 3,70 & 0,465 & 2,90 & 4,00 & 4,70 & 0,36 & 0,065 & 0,001 & 0,955 \\
\hline
\end{tabular}


No presente estudo, não houve diferença para nenhuma das características de desempenho avaliadas. Os valores de IMS permaneceram dentro dos recomendados pelo NRC (2007), que varia entre 1,0 e 1,5 kg/dia. 0 GMD não diferiu entre os tratamentos, mantendo-se entre 324 a 339 g/dia. Cirne et al. (2013) encontraram um ganho de peso médio de 300 g/dia ao avaliar cordeiros mestiços Santa Inês submetidos a uma dieta exclusiva de concentrado, com diferentes teores de proteína. Ao teor de $18 \%$ de PB, 0 GMD foi de 342 g/dia e a eficiência alimentar de 285 g/kg MS, valores semelhantes aos encontrados neste estudo.

Sabe-se que dietas com baixo teor de fibra têm sido utilizadas na terminação de cordeiros almejando bom desempenho, redução do tempo de confinamento e produção de carne de boa qualidade (GALLO et al., 2014). Tais dietas apresentam maiores concentrações de energia metabolizável, tornando mais eficiente o uso da energia líquida para o ganho, uma vez que o requisito de energia para a manutenção é diluído, redirecionando a parcela de energia para a deposição de tecido, na forma de proteína ou gordura (NRC, 2007).

Assim sendo, o alto GMD e eficiência alimentar encontrados neste estudo podem ser associados ao teor de concentrado da dieta utilizada, que possivelmente uniformizou a taxa de ganho e permitiu a maior expressão do potencial genético dos animais, não diferindo entre os tratamentos.

Corroborando com os resultados obtidos por Polizel et al. (informação verbal) $^{1}$, a monensina sódica na dose de $15 \mathrm{mg} / \mathrm{kg}$ MS não resultou em melhora sobre nenhuma das características de desempenho em relação ao tratamento controle, sem monensina, indicando, como relatado, que para cordeiros a dose ideal seria menor.

O peso final não variou entre os tratamentos, assim como o RCF, que apresentou valores similares aos encontrados na literatura, variando entre $46 \mathrm{e}$ $48,0 \%$, próximos aos observados por Urano et al. (2006) ao submeter cordeiros Santa Inês à dietas com elevada proporção de concentrado, que apresentaram valores de RCQ e RCF de 48,2 e 46,7\%, respectivamente. Os autores também observaram AOL com valores próximos ao deste estudo, que variou 14,6 a 17 $\mathrm{cm}^{2}$, sendo considerada satisfatória.

\footnotetext{
${ }^{1}$ Fornecido por Daniel M. Polizel. Low doses of monensin alter the rumen parameters and increase the performance of lambs fed high concentrate diets. Mensagem recebida por dmpolizel@gmail.com em 28 mai. 2019. (Dados ainda não publicados)
} 
A EGS que variou de 2,3 a 2,9 mm, que pode ser classificada como um alto grau de acabamento para o genótipo utilizado neste estudo (1/2 Dorper + 1/2 Santa Inês), e propicia maior proteção contra o resfriamento (SOUSA et al., 2008).

A qualidade da carne envolve diversos aspectos como $\mathrm{pH}$, cor, capacidade de retenção de água, textura, composição tecidual (quantidade de músculo, gordura e tecido conjuntivo), sabor e suculência, bem como fatores pós abate, como processamento e armazenamento (LAWRIE, 2005; MILLER 1994). Neste estudo, não foram encontradas diferenças para a maioria das características de qualidade de carne avaliadas, em que os valores de FC variaram de 29,9 a $40,3 \mathrm{~N}$, podendo ser classificada como maciez mediana (CEZAR; SOUZA, 2007).

Durante o tempo de exposição no display, o tratamento MON apresentou os menores valores de $L^{*}$ no tempo 1 , igualando-se aos demais nos tempos 3 e 5 . Os valores de $L^{*}$ indicam a luminosidade da carne, influenciados pela quantidade de água presente na superfície no momento da mensuração (MCGUIRE, 1992). Quanto maiores os valores de $L^{*}$, mais pálida é a carne (MILTENBURG et al., 1992). Em ovinos, são descritos valores médios de 31,36 a 38,0 para L* (BRESSAN et al., 2001), próximos aos encontrados nos tempos 0,3 e 5 de exposição no display e maiores que os observados no tempo 1, que apesar de apresentar interação, demonstrou variação muito pequena em relação aos valores citados na literatura.

No tocante às características sensoriais, a peroxidação lipídica tem influência sobre o sabor, cor e odor desagradáveis, afetando a preferência do consumidor. Os lipídios, em particular os poli-insaturados são os substratos mais susceptíveis à oxidação e aos danos causados pelos radicais livres (GEORGIEVA, 2005). Neste estudo, o tratamento SeE apresentou os menores valores de TBARS em comparação aos demais, demonstrando-se efetivo em manter baixos níveis de oxidação lipídica durante o tempo de exposição, em contraste ao LKR.

A produção endógena de íons superóxido e peróxido de hidrogênio pode desencadear a peroxidação lipídica em membranas biológicas expostas. Os radicais de ácidos graxos formados reagem com o oxigênio formando o peroxiradical de ácido graxo e este propaga a peroxidação de mais moléculas, 
formando hidroperóxidos e novos radicais de ácidos graxos, gerando uma cadeia de oxidação de muitas moléculas (HALLIWEL; GUTTERDGE, 1989).

A vitamina $E$ (a-tocoferol) fornece átomos de hidrogênio para as membranas celulares e impede a reação em cadeia que se propaga nas membranas lipídicas (ESTEUBAUER et al., 1989). O selênio é um componente da selenoenzima GSH-Px, que age como antioxidante e ajuda a prevenir danos nos tecidos causados pelos radicais livres (ANDRÉS et al., 1999). A atividade de GSH-Px no plasma contribui para a defesa antioxidante de tecidos animais, catalisando a redução de peróxidos de hidrogénio e de peróxidos lipídicos (HALLIWELL; CHIRICO, 1993).

Observou-se um aumento da atividade enzimática das peroxidases no plasma entre os dias 0 e 29 no tratamento LKR. As peroxidases são um grupo de enzimas oxidoredutases que catalisam a reação de redução do $\mathrm{H}_{2} \mathrm{O}_{2}$ em $\mathrm{H}_{2} \mathrm{O}$, atuando no combate às ERO, com papel de desintoxicação celular (PÜTTER, 1974).

Após o organismo detectar um aumento da produção de $\mathrm{H}_{2} \mathrm{O}_{2}$, a resposta inicial seria o aumento da atividade enzimática das peroxidases. Neste caso, a lignina estaria trabalhando na estabilização do $\mathrm{OH}$, através da doação do íon $\mathrm{H}^{+}$do $\mathrm{OH}$ fenólico para $\circ \mathrm{H}_{2} \mathrm{O}_{2}$, que logo após o aumento na produção de peroxidases seria degradado em $\mathrm{H}_{2} \mathrm{O}$, estabilizando os níveis de $\mathrm{H}_{2} \mathrm{O}_{2}$. Entre os dias 29 e 54, foi observada a redução da atividade das peroxidases, podendo ser explicada pela estabilização dos níveis de $\mathrm{H}_{2} \mathrm{O}_{2}$, $\mathrm{O}$ que também foi encontrado durante o período de avaliação.

Sabe-se que a lignina Kraft é rica em guaiacol, reportado na literatura por possuir derivados com grande atividade antioxidante, capazes de atuar na redução de uma variedade de radicais livres (ANOUAR et al., 2009). No entanto, ainda há alguma falta de informação sobre essa atividade (GALANO; LÉON-CARMONA; ALVAREZ-IDABOY, 2012). Fujisawa et al. (2002) propuseram o mecanismo de ação do guaiacol baseado na transferência de $\mathrm{H}^{+}$ do $\mathrm{OH}$ fenólico. É conhecido que o guaiacol reage com $\circ \mathrm{H}_{2} \mathrm{O}_{2}$ e as peroxidases, resultando em diversos produtos (BOOTH; SOUNDERS, 1956), e que a reação estequiométrica ocorre à medida que um mol de $\mathrm{H}_{2} \mathrm{O}_{2}$ oxida um mol de guaiacol, alterando as concentrações de $\mathrm{H}_{2} \mathrm{O}_{2}$ (PÜTTER, 1974), o que 
possivelmente contribuiu para o aumento da atividade das peroxidases $\mathrm{e}$ estabilização dos níveis de $\mathrm{H}_{2} \mathrm{O}_{2}$ dos animais tratados com LKR.

A catalase é uma enzima integrante do grupo das peroxidases, que catalisa a reação de redução do $\mathrm{H}_{2} \mathrm{O}_{2}$ em $\mathrm{H}_{2} \mathrm{O}$ e $\mathrm{O}_{2}$ (DRÖGE, 2002), protegendo as células contra o dano oxidativo. No tratamento MON foi observado decréscimo da atividade de catalase em comparação ao CTL aos 29 dias, e ao SeE aos 54 dias de avaliação. Singh et al. (2006) observaram inibição da atividade enzimática de catalase em células testiculares de ratos tratadas in vitro com monensina. Esta inibição justificou uma maior produção de EROs pela monensina, pois, de acordo com Orrenius et al. (1982), a catalase não é responsável pela remoção total de $\mathrm{H}_{2} \mathrm{O}_{2}$ celular, mas atua em conjunto com a GSH-Px, que por sua vez é mais eficiente na proteção celular contra o dano oxidativo.

Charvat e Arrizabalaga (2016) encontraram que o tratamento com monensina sódica contra Toxoplasma gondii gera espécies reativas ao oxigênio, induzindo o estresse oxidativo, bem como perda no potencial de membrana e eventual ruptura da arquitetura mitocondrial do parasita. Ketola et al. (2010) descobriram grande potencial indutor de estresse oxidativo na monensina em células de câncer de próstata. Tais resultados sugerem que a monensina é um potencial indutor de estresse oxidativo, no entanto, a produção de antioxidantes endógenos é um mecanismo de proteção às células contra os danos, o que explica o aumento da atividade das peroxidases aos 54 dias no tratamento MON em relação ao CTL e LKR.

Em relação às características ruminais, o tratamento LKR apresentou 0 maior número de animais com lesões no epitélio ruminal. Sabe-se que o mesmo é sensível à qualidade da dieta, refletindo-se nos tipos de ácidos graxos voláteis formados durante o processo de fermentação (SAKATA; TAMATE, 1978). Mesmo por se tratar de uma dieta com elevada proporção de concentrado, conhecida pelo risco de acidose, que por sua vez pode ocasionar quadros de ruminite, os demais tratamentos não apresentaram graus elevados de lesão no epitélio ruminal.

Apesar dos efeitos benéficos do composto fenólico guaiacol presente na lignina Kraft, o mesmo também é conhecido pela sua alta toxicidade às células e, dependendo da dose, pode ser corrosivo aos tecidos (TISSERAND, 
2014). Castillejos, Casalmiglia e Ferret (2006) reportaram efeitos negativos de diferentes doses de guaiacol sobre a fermentação microbiana ruminal, relacionados à produção de ácidos graxos voláteis. No entanto, as informações sobre o efeito do guaiacol no rúmen são escassas.

O guaiacol na medicina humana deve ser utilizado abaixo do nível de toxicidade, sendo a dose fator de grande importância para o uso. Possivelmente a concentração de guaiacol presente na lignina purificada utilizada neste estudo ocasionou o aparecimento de lesões na parede ruminal. 
Nas condições deste estudo e na dose utilizada, a lignina Kraft não apresentou efeito sobre o desempenho e características de carcaça e qualidade de carne, sequer ação protetiva ao epitélio da parede ruminal de cordeiros alimentados com dietas com elevada proporção de concentrado. No entanto, demonstrou potencial atividade antioxidante.

Em contraste com a lignina Kraft, a administração dietética de selênio e vitamina $E$ foi eficaz contra a peroxidação lipídica na carne durante o período de exposição, aumentando a vida útil do produto.

A monensina sódica a $15 \mathrm{mg} / \mathrm{kg}$ MS não apresentou efeito sobre as características de desempenho estudadas, corroborando com resultados encontrados na literatura de que para cordeiros a dose ideal seria menor.

Existem poucas pesquisas e resultados publicados a respeito da lignina purificada. Por se tratar de uma macromolécula complexa, seu mecanismo de extração ainda é baseado em hipóteses. Mais estudos são necessários para identificar as propriedades da molécula, assim como a melhor dose a ser utilizada. 


\section{REFERÊNCIAS}

AGARWAL, A.; GUPTA, S.; SHARMA, R. Role of oxidative stress in female reproduction. Reproductive Biology and Endocrinology, London, v. 28, n. 3, art. 28, p. 1-21, 2005.

AMEN-CHEN, C.; PAKDEL, H.; ROY, C. Production of monomeric phenols by thermochemical conversion of biomass: a review. Bioresource Technology, Barking, v. 79, p. 277-299, 2001.

AMEN-CHEN, C.; PAKDEL, H.; ROY, C. Separation of phenols from Eucalyptus wood tar. Biomass \& Bioenergy, Oxford, v. 13, p. 25-37, 1977.

AMERICAN MEAT SCIENCE ASSOCIATION - AMSA. Research guidelines for cookery, sensory evaluation and instrumental tenderness measurements of fresh meat. Chicago, IL: AMSA, 1995.

AMES, B. N.; SHIGENAGA, M. K.; HAGEN, T. M. Oxidants, antioxidants, and the degenerative diseases of aging. Proceedings of the National Academy of Sciences, Washington, v. 90, p. 7915-7922, 1993.

ANDRÉS, S. et al. Relationships between some soil parameters and the blood glutathione peroxidase activity of grazing sheep. The Veterinary Record, London, v. 141, p. 267-268, 1997.

ANDRÉS, S. et al. Temporal variations in blood glutathione peroxidase (GSHPx) activity in sheep at pasture in a Mediterranean area. Veterinary Journal, London, v. 157, p. 186-188, 1999.

ANOUAR, E. et al. Free radical scavenging properties of guaiacol oligomers: a combined experimental and quantum study of the guaiacyl-moiety role. Journal of Physical Chemistry A, Washington, v. 113, n. 50, p. 13881-13891, 2009.

ASSOCIATION OF OFFICIAL AGRICULTURAL CHEMISTS - AOAC. Official methods of analysis of AOAC International. 16th ed. Arlington: AOAC, v.2, p.10-11, 1995.

AYYACHAMY, M. et al. Lignin: untapped biopolymers in biomass conversion technologies. Biomass Conversion and Biorefinery, Berlin, v. 3, p. 255-267, 2013.

BAE, H. D. et al. Effects of condensed tannins on endoglucanase activity and filter paper digestion by Fibrobacter succinogenes S85. Applied

Environmental Microbiology, Washington, v. 59, p. 2132-2138, 1993.

BAIMARK, Y.; NIAMSA, N. Study on wood vinegars for use as coagulating and antifungal agents on the production of natural rubber sheets. Biomass \&

Bioenergy, Oxford, v. 33, p. 994-998, 2009. 
BAURHOO, B.; PHILLIP, L.; RUIZ-FERIA, C. A. Effects of purified lignin and mannan oligosaccharides on intestinal integrity and microbial populations in the ceca and litter of broiler chickens. Poultry Science, Urbana, v. 86, p. 10701078, 2007.

BEHNE, D.; KYRIAKOPOULOS, A. Mammalian selenium-containing proteins. Annual Review of Nutrition, Palo Alto, v. 21, p. 453-473, 2001.

BERGEN, W. G.; BATES, D. B. Ionophores: their effect on production efficiency and mode of action. Journal of Animal Science, Champaign, v. 58, n. 61, p. 1465-1483, 1984.

BESLE, J. M.; CORNU, A.; JOUANY, J. P. Roles of structural phenylpropanoids in forage cell wall digestion. Journal of the Science and Food and Agriculture, Elmhurst, v. 64, p. 171-190, 1994.

BHAGAVAN, N. V. Biochemistry. 2nd ed. Philadelphia, PA: J. B. Lippincott, 1978.

BIGHAM, M. L.; McMANAUS, W. R. Whole wheat grain feeding of lambs: effects of roughage and wheat grain mixtures. Australian Journal of Agriculture Research, East Melbourne, v. 26, p. 1053-1062, 1975.

BOOTH, H.; SOUNDERS, B. C. Studies in peroxidase action, part X: the oxidation of phenols. Journal of the Chemical Society, London, p. 940-948, 1956.

BOUDET, A. M., GRIMA-PETTENATI, J. Lignin genetic engineering. Molecular Breeding, Dordrecht, v. 2, p. 25-39, 1996.

BRESSAN, M. C. et al. Efeito do peso ao abate de cordeiros Santa Inês e Bergamácia sobre as características físicoquímicas da carne. Ciência e Tecnologia de Alimentos, Campinas, v. 21, p. 293-303, 2001.

BRIVIBA, K.; SIES, H. Non-enzymatic antioxidants defence system. In: FREI, B. (Ed.) Natural antioxidants in human health and disease. San Diego: Academic Press, 1994. p.107-128.

BURT, S. Essential oils: their antibacterial properties and potential applications in foods - a review. International Journal of Food Microbiology, Amsterdam, v. 94, p. $223-253,2004$.

CARDOSO, E. O. Dieta de alto grão para bovinos confinados: viabilidade econômica e qualidade da carne. 2012. 66 f. Dissertação (Mestrado em Zootecnia) - Universidade Estadual do Sudoeste da Bahia, Itapetinga, 2012.

CASTILLEJOS, L.; CALSAMIGLIA, S.; FERRET, A. Effect of essential oil active compounds on rumen microbial fermentation and nutrient flow in in vitro systems. Journal of Dairy Science, Lancaster, v. 89, p. 2449-2658, 2006. 
CASTILLEJOS, L. et al. Effects of a specific blend of essential oil compounds and the type of diet on rumen microbial fermentation and nutrient flow from a continuous culture system. Animal Feed Science and Technology, v.119:29, 2005.

CASTILLO, C. et al. Oxidative status during late pregnancy and early lactation in dairy cows. The Veterinary Journal, London, v. 169, p. 286-292, 2005.

CATIGNANI, G. L.; CARTER, M. E. Antioxidant properties of lignin. Journal of Food Science, Malden, v. 47, p. 1745-1748, 1982.

CELI, P. The role of oxidative stress in small ruminants ' health and production. Revista Brasileira de Zootecnia, Viçosa, v. 39, p. 348-363, 2010.

CELI, P. et al. Selenium supplementation increases wool growth and reduces faecal egg counts of Merino weaners in a selenium-deficient area. Animal Production Science, Melbourne, v. 50, n. 7, p. 688-692, 2010.

CEZAR, M. F.; SOUZA, W. H. Ovine and caprine carcasses: generation, evaluation and classification. Uberaba, MG: Agropecuária Tropical, 2007.

CHARVAT, R.; ARRIZABALAGA, G. Oxidative stress generated during monensin treatment contributes to altered Toxoplasma gondii mitochondrial function. Scientific Reports, London, v. 6, art. 22977, 2016.

CHIRASE, N. K., GREENE, W. L., PURDY, C. W., LOAN, R. W., AUVERMANN, B. W., PARKER, D. B., WALBORG JR, E. F., STEVENSON, D. E., XU, Y., KLAUNIG, J. E. Effect of transport stress on respiratory disease, serum antioxidant status, and serum concentrations of lipid peroxidation biomarkers in beef cattle. American Journal of Veterinary Research, V.65:6, 2004.

CIRNE, L. G. A. et al. Desempenho de cordeiros em confinamento alimentados com dieta exclusiva de concentrado com diferentes porcentagens de proteína. Arquivo Brasileiro de Medicina Veterinária e Zootecnia, Belo Horizonte, v. 65, n. 1, p. 262-266, 2013.

CLAUSS, M.; HUME, I. D.; HUMMEL, J. Evolutionary adaptations of ruminants and their potential relevance for modern production systems. Animal, Cambridge, v. 4, n. 7, p. 979-992, 2010.

COMMISSION INTERNATIONALE DE L'ECLAIRAGE - CIE. Recommendations on uniform color spaces - color equations, psychometric color terms. Paris: CIE, 1986.

DI TRANA, A. et al. The effect of hot season and nutrition on the oxidative status and metabolic profile in dairy goats during mid lactation. Animal Science, Champaign, v. 82, p. 717-722, 2006. 
DONG, X. et al. Antimicrobial and antioxidant activities of lignin from residue of corn stover to ethanol production. Industrial Crops and Products, Amsterdam, v. 34, p. 1629-34, 2011.

DRÖGE, W. Free radicals in the physiological control of cell function.

Physiological Reviews, Bethesda, v. 82, p. 47-95, 2002.

DUNLOP, R. H. Pathogenesis of ruminant lactic acidosis. Advances in Veterinary Science \& Comparative Medicine, New Jersey, v. 16, p. 259-302, 1972.

ESTEUBAUER, $\mathrm{H}$. et al. The role of vitamin $\mathrm{E}$ and carotenoids in preventing oxidation low density lipoproteins. Annals of the New York Academy of Sciences, New York, v. 570, p. 254-267, 1989.

FERNANDES, A. R. M. et al. Características da carcaça e da carne de bovinos sob diferentes dietas em confinamento. Arquivo Brasileiro de Medicina Veterinária e Zootecnia, Belo Horizonte, v. 60, n. 1, p. 139-147, 2008.

FERNANDES, R. P. P. Uso de extratos antioxidantes naturais obtidos de ervas aromáticas na elaboração de produtos a base de carne ovina. 2015. $253 \mathrm{f}$. Tese (Doutorado) - Faculdade de Zootecnia e Engenharia de Alimentos, Universidade de São Paulo, Pirassununga, 2015.

FLOHE, L.; GUNZLER, W. A.; SCHOCK, H. H. Glutathione peroxidase: a selenoenzyme. FEBS Letters, Amsterdam, v. 32, p. 132-134, 1973.

FREI, B. Natural antioxidants in human health and disease. San Diego: Academic Press, 1994.

FUJISAWA, S. et al. Antioxidant and prooxidant action of eugenol-related compounds and their cytotoxicity. Toxicology, Amsterdam, v. 177, n. 1, p. 3954, 2002.

GALANO, A.; LEÓN-CARMONA, J. R.; ALVAREZ-IDABOY, J. R. Influence of the environment on the protective effects of guaiacol derivatives against oxidative stress: mechanisms, kinetics, and relative antioxidant activity. The Journal of Physical Chemistry B, Washington, v. 116, p. 7129-7137, 2012.

GALLO, S. B et al. Whole grain diet for feedlot lambs. Small Ruminant Research, Amsterdam, v. 120, p. 185-188, 2014.

GALYEAN, M. L.; HUBBERT, M. E. Traditional and alternative sources of fiber roughage values, effectiveness, and concentrations in starting and finishing diets. In: PLAINS NUTRITION COUNCIL SPRING CONFERENCE, 2012, San Antonio. [Proceedings...] Amarillo: Texas A\&M, 2012. p. 74-97.

GARAY, E. B.; GARCÍA, J. A (2009). Acidosis ruminal y sus consecuencias. Disponível em: <http://www.fmvz.unam.mx/bovinotecnia/BtRgClig013.pdf>. Acesso em: jun. 2018. 
GEORGIEVA, N. V. Oxidative stress as a factor of disrupted ecological oxidative balance in biological systems - a review. Bulgarian Journal of Veterinary Medicine, Stara Zagora, v. 8, n. 1, p. 1-11, 2005.

GOLDEN, M. H. N.; RAMDATH, D. Free radicals in the pathogenesis of kwashiorkor. Proceedings of the Nutrition Society, Cambridge, v. 46, p. 5368, 1987.

GOMES, I. P. O. Uso de ionóforos na alimentação de ruminantes. Lages: Universidade do Estado de Santa Catarina, 2011.

GOSSELINK, J. A. et al. Co-ordination network for lignin-standardisation, production and applications adapted to market requirements (EUROLIGNIN). Industrial Crops and Products, Amsterdam, v. 20, p. 121-129, 2004.

GUILLÉN, M. D.; IBARGOITIA, M. L. GC/MS analysis of lignin monomers, dimers and trimers in liquid smoke flavourings. Journal of the Science of Food and Agriculture, Oxford, v. 79, p. 1889-1903, 1999.

GUILLÉN, M. D.; MANZANOS, M. J. Study of the components of a solid smoke flavouring preparation. Food Chemistry, Oxford, v. 55, p. 251-257, 1996.

GUILLEN, M. D.; MANZANOS, M. J. Study of the volatile composition of an aqueous oak smoke preparation. Food Chemistry, Oxford, v. 79, p. 283-292, 2002.

HALLIWELL, B. Albumin - an important extracellular antioxidant. Biochemical Pharmacology, London, v. 37, p. 569-571, 1988.

HALLIWELL, B.; CHIRICO, S. Lipid peroxidation: its mechanism, measurement, and significance. American Journal of Clinical Nutrition, New York, v. 57, p. 715-725, 1993.

HALLIWEL, B.; GUTTERDGE, J. M. C. Free radicals in biology and medicine. 2th ed. Oxford: Clarenton Press, 1989.

HANEY JR., M. E.; HOEHN, M. M. Monensin, a new biologically active compound. I. Discovery and isolation. Antimicrobial Agents and Chemotherapy, Bethesda, v. 7, p. 349-352, 1967.

HEINONEN, I. M.; MEYER, A. S.; FRANKEL, E. N. Antioxidant activity of berry phenolics on human low-density lipoprotein and liposome oxidation. Journal of Agricultural and Food Chemistry, Easton, v. 46, p. 4107-4112, 1998.

HIRAFUJI, M. Inhibition of prostaglandin 12 biosynthesis in rat dental pulp by phenolic dental medicaments. Japanese Journal of Pharmacology, Kyoto, v. 36, n. 4, p. 544-546, 1984.

HORTON, G. M. J; STOCKDALE, P. H. G. Oocyst discharge, rumen metabolism and performance of early weaned lambs with naturally occurring 
coccidiosis fed monensin. Canadian Veterinary Journal, Ottawa, v. 22, n. 6, p. 175-178, 1981.

HUTCHESON, D. P.; COLE, N. A. Vitamin E and selenium for yearling feedlot cattle. Federation Proceedings, Bethesda, v. 44, p. 549, 1985.

HWANG, Y. H. et al. Antimicrobial effect of the wood vinegar from Cryptomeria japonica sapwood on plant pathogenic microorganisms. Journal of Microbiology and Biotechnology, Seoul, v. 15, p. 1106-1109, 2005.

INGRAHAM, R. H.; STANLEY, R. W.; WAGNER, W. C. Seasonal effects of tropical climate on shaded and nonshaded cows as measured by rectal temperature, adrenal cortex hormones, thyroid hormone, and milk production.

American Journal of Veterinary Research, Shaumburg, v. 40, p. 1792-1797, 1979.

JACOB, R. A. The integrated antioxidant system. Nutrition Research, New York, v. 15, p. 755-766, 1995.

JANERO, D. R. Malondialdehyde and thiobarbituric acid-reactivity as diagnostic indices of lipid peroxidation and peroxidative tissue injury. Free Radical

Biology and Medicine, New York, v. 9, p. 515-540, 1990.

JOYNER JR., A. E. et al. Effect of monensin on growth, feed efficiency and energy metabolism of lambs. Journal of Animal Science, Champaign, v. 48, p. 1065-1069, 1979.

KEHRER, J. P.; SMITH, C. V. Free radicals in biology: sources, reactivities, and roles in the etiology of human dieseases. In: FREI, B. (Ed.) Natural antioxidants in human health and diseases. San Diego: Academic Press, 1994. p. 25-62.

KERRY, J. P. et al. Endogenous and exogenous a-tocopherol supplementation: effects on lipid stability (TBARS) and warmed-over flavor (WOF) in porcine M Longissimus dorsi roasts held in aerobic and vacuum packs. Food Research International, Amsterdam, v. 31, p. 211-216, 1999.

KETOLA, K., VAINIO, P., FEY, V., KALLIONIEMI, O., \& ILJIN, K. Monensin Is a Potent Inducer of Oxidative Stress and Inhibitor of Androgen Signaling Leading to Apoptosis in Prostate Cancer Cells. Therapeutic Discovery, v.9(12), p.3175-3186, 2010.

KÖHRLE, J. The selenoenzyme family of deiodinase isozymes controls local thyroid hormone availability. Reviews in Endocrine and Metabolic Disorders, v. 1(1-2), p.49-58, 2000.

KÖPPEN CLIMATE CLASSIFICATION. Disponível em: https://www.britannica.com/science/Koppen-climate-classification. Acesso em: 08/06/2019. 
LAWOKO, M.; HENRIKSSON, G.; GELLERSTEDT, G. Structural differences between the lignin-carbohydrate complexes present in wood and in chemical pulps. Biomacromolecules, Washington, v. 6, n. 6, p. 3467-3473, 2005.

LAWRIE, R. A. Ciência da carne. 6. ed. Porto Alegre: Artmed, 2005.

LEE, K. W.; EVERTS, H.; BEYNEN, A. C. Essential oils in broiler nutrition. International Journal of Poultry Science, Faisalabad, v. 3, n. 12, p. 738-752, 2004.

LIU, H. et al. Facile synthesis and promising antibacterial properties of a new guaiacol-based polymer. Polymer, Guildford, v. 52, n. 9, p. 1908-1916, 2011.

LOO, A. Y.; JAIN, K.; DARAH, I. Antioxidant activity of compounds isolated from the pyroligneous acid, Rhizophora apiculate. Food Chemistry, Oxford, v. 107, p. 1151-1160, 2008.

LOO, A. Y.; JAIN, K.; DARAH, I. Antioxidant and radical scavenging activities of the pyroligneous acid from a mangrove plant, Rhizophora apiculate. Food Chemistry, Oxford, v. 104, p. 300-307, 2007.

LORA, J. H.; GLASSER, W. G. Recent industrial applications of lignin: a sustainable alternative to nonrenewable materials. Journal of Polymers and the Environment, Dordrecht, v. 10, p. 39-48, 2002.

LYKKESFELDT, J.; SVENDSEN, O. Oxidants and antioxidants in disease: oxidative stress in farm animals. The Veterinary Journal, London, v. 173, p. 502-511, 2007.

MA, X. H. et al. Isolation and bioactivities of organic acids and phenols from walnut shell pyroligneous acid. Journal of Analytical and Applied Pyrolysis, Amsterdam, v. 91, p. 338-343, 2011.

MAGLIOCCA, F. C. et al. Efeito da niacina e da monensina sódica no desempenho de novilhos em confinamento. Pesquisa Agropecuária Brasileira, Brasília, v. 29, n. 6, p. 983-988, 1994.

MAKKAR, H. P. S.; FRANCIS, G.; BECKER, K. Bioactivity of phytochemicals in some lesser-known plants and their effects and potential applications in livestock and aquaculture production systems. Animal, Cambridge, v. 1, n. 9, p. 1371-1391, 2007.

MARTIN, G. B.; KADOKAWA, H. "Clean, green and ethical" animal production case study: reproductive efficiency in small ruminants. The Journal of Reproduction and Development, Tokyo, v. 52, p. 145-152, 2006.

MARTINS, A. S. et al. Novas perspectivas sobre a utilização de monensina sódica para cordeiros confinados. In: BALIEIRO, J. C. C. et al. (Orgs.). Novos desafios da pesquisa em nutrição e produção animal. Pirassununga, SP: Editora 5D, 2018. cap. 15, p. 262-277. 
McALLISTER, T. A. et al. Effect of condensed tannins from birdsfoot trefoil on endoglucanase activity and the digestion of cellulose filter paper by ruminal fungi. Canadian Journal of Microbiology, Ottawa, v. 40, n. 4, p. 298-305, 1994.

McGUFFEY, R. K.; RICHARDSON, L. F.; WILKINSON, J. I. D. Ionophores for dairy cattle: current status and future outlook. Journal of Dairy Science, Lancaster, v. 84, suppl. E, p. 194-203, 2001.

McGUIRE, R. Reporting of objective color measurements. HortScience, Alexandria, v. 27, n. 12, p. 1254-1255, 1992.

McINTOSH, F. M.; WILLIAMS, P.; LOSA, R.; WALLACE, R.J.; BEEVER, D.A; NEWBOLD, C.J. Effects of essential oils on ruminal microorganisms and their protein metabolism. Applied and Environmental Microbiology, Washington, v.69, n.8, p. 5011-5014, 2003.

MEYER, A. S. et al. Inhibition of human low-density lipoprotein oxidation in relation to composition of phenolic antioxidants in grapes (Vitis vinifera).

Journal of Agricultural and Food Chemistry, Easton, v. 45, p. 1638-1643, 1997.

MILLEN, D. D. et al. A snapshot of management practices and nutritional recommendations used by feedlot nutritionists in Brazil. Journal of Animal Science, Champaign, v. 87 p. 3427-3439, 2009.

MILLER, J. K.; BRZEZINSKA-SLEBODZINSKA, E.; MADSEN, F. C. Oxidative stress, antioxidants, and animal function. Journal of Dairy Science, Lancaster, v. 76, n. 9, p. 2812-2823, 1993.

MILLER, R. K. Quality characteristics. In: KINSMAN D. M.; KOTULA A. W.; BREIDENSTEIN, B. C. (Eds). Muscle foods. Boston: Springer, 1994. p296332.

MILLY, P. J.; TOLEDO, R. T.; RAMAKRISHNAN, S. Determination of minimum inhibitory concentrations of liquid smoke fractions. Journal of Food

Science, Malden, v. 70, n. 1, p.12-17, 2004.

MILTENBURG, G.A.J.; WENSING, T.H.; SMULDERS, F.J.M. et al. Relationship between blood hemoglobin, plasma and tissue iron, muscle heme pigment, and carcass color of veal. Journal of Animal Sciences, v.70, p.2766-2772, 1992.

MIMURA, T. et al. Hydroxyl radical scavenging effects of guaiacol used in traditional dental pulp sedation: reaction kinetic study. BioMed Research International, London, v. 26, p. 139-145, 2005.

MIYAKE, Y. et al. Identification of coumarins from lemon fruit (Citrus limon) as inhibitors of in vitro tumor promotion and superoxide and nitric oxide generation. Journal of Agricultural and Food Chemistry, Easton, v. 47, p. 3151-3157, 1999. 
MORAN, L. K.; GUTTERIDGE, J.; QUINLAN, G. J. Thiols in cellular redox signalling and control. Current Medicinal Chemistry, Hilversum, v. 8, p. 763, 2001.

MORRISON, I. M. Changes in the lignin and hemicellulose concentrations of ten varieties of temperate grasses with increasing maturity. Grass and Forage Science, Oxford, v. 35, p. 287-293, 1980.

MU, J;, UEHARA, T.; FURUNO, T. Effect of bamboo vinegar on regulation of germination and radicle growth of seed plants II: composition of moso bamboo vinegar at different collection temperature and its effects. Journal of Wood Science, Tokyo, v. 50, p. 470-476, 2004.

NAGARAJA, T. G. Manipulation of the rumen to minimize the problems. In: SIMPOSIO DE NUTRICAO DE RUMINANTES, 3., 2011, Botucatu. Anais eletrônicos... Botucatu: Departamento de Melhoramento e Nutrição Animal/UNESP, 2011. [CD-ROM]

NAGARAJA, T. G.; LECHTENBERG, K. F. Acidosis in feedlot cattle. Veterinary Clinics of North America: Food Animal Practice, Philadelphia, v. 2, p. 333-350, 2007.

NAGARAJA, T. G.; TITGEMEYER, E. C. Ruminal acidosis in beef cattle: the current microbiological and nutritional outlook. Journal of Dairy Science, Lancaster, v. 90, p. 17-38, 2007.

NAGARAJA, T. G. et al. Manipulation of ruminal fermentation. In: HOBSON, P. N.; STEWART, C. S. (Eds.) The rumen microbial ecosystem. 2nd ed. London: Chapman \& Hall, 1997. p. 524-632.

NATIONAL RESEARCH COUNCIL - NRC. Nutrient requirements of small ruminats: sheep, goats, cervids and new world camelids. Washington, DC: National Academies Press, 2007.

NICODEMO, M. L. F. Uso de aditivos na dieta de bovinos de corte. Campo Grande: Embrapa Gado de Corte, 2001.

NOCKELS, C. F.; JACKSON, D. W.; BERRY, B. W. Optimum level of monensin for fattening lambs. Journal of Animal Science, Champaign, v. 47, p. 788-790, 1978.

NOTTER, D. R.; KELLY, R. F.; MCCLAUGHERTY, F. S. Effects of ewe breed and management system on efficiency of lamb production, II: lamb growth, survival and carcass characteristics. Journal of Animal Science, Champaign, v. 69 , n. 1, p. 22-23, 1991.

NOVILLA, M. N. The veterinary importance of the toxic syndrome induced by ionophores. Veterinary and Human Toxicology, Manhattan, v. 34, n. 1, p. 6670, 1992.

OH-HARA, T. et al. Antimicrobial spectrum of lignin-related pine cone extracts of Pinus parviflora Sieb. et Zucc. In Vivo, Athens, v. 4, n. 1, p. 7-12, 1990. 
OH-HARA, T. et al. Lignified materials as potential medicinal resources. II. Prevention of pathogenic bacterial infections in mice. In Vivo, Athens, v. 4, p. 221-223, 1990.

OLIVO, R. Alterações oxidativas em produtos cárneos. In: OLIVO, R. et. al. 0 mundo do frango. São Paulo: Rubison Olivo, 2006. cap. 44, p. 533-542.

OLSON, O. E.; PALMER, I. S.; CARY, E. E. Modification of the official fluorimetric method for selenium in plants. Journal - Association of Official Analytical Chemists, Washington, v. 58, p. 117-121, 1975.

ORAMAHI, H. A.; YOSHIMURA, T. Antifungal and antitermitic activities of wood vinegar from Vitex pubescens Vahl. Journal of Wood Science, Tokyo, v. 59, p. 344-350, 2013.

ORRENIUS, S. et al. Compartmentation of detoxification reactions. Biological reactive intermediates part A. New York, p. 395-405, 1982.

OWENS, F. N. et al. Acidosis in cattle: a review. Journal of Animal Science, Champaign, v. 76, n. 1, p. 275-286, 1998.

PAN, X. et al. Organosolv ethanol lignin from hybrid poplar as a radical scavenger: relationship between lignin structure, extraction conditions, and antioxidant activity. Journal of Agricultural and Food Chemistry, Easton, v. 54, p. 5806-5813, 2006.

PARK, C. K. et al. Molecular mechanism for local anesthetic action of eugenol in the rat trigeminal system. Pain, Amsterdam, v. 144, p. 84-94, 2009.

PAULINO, P. V. R. et al. Dietas sem forragem para terminação de animais ruminantes. Revista Científica de Produção Animal, Areia, v. 15, n. 2, p. 161-172, 2013.

PEREZ, J. et al. Biodegradation and biological treatments of cellulose, hemicellulose and lignin: an overview. International Microbiology, Barcelona, v. 5, p. 53-63, 2002.

PERRY, T. W.; BEESON, W. M.; MOHLER, M. T. Effect of monensin on beef cattle performance. Journal of Animal Science, Champaign, v. 42, p. 761-765, 1976.

PHILLIP, L. E.; IDZIAK, E. S.; KUBOW, S. The potential use of lignin in animal nutrition, and in modifying microbial ecology of the gut. In: East. Nutr. Conf. Animal Nutrition Association of Canada, Montreal, Qu'ebec, Canada, pp. 165$184,2000$.

PIMENTA, A. S. et al. Evaluation of acute toxicity and genotoxicity of liquid products from pyrolysis of Eucalyptus grandis wood. Archives of

Environmental Contamination and Toxicology, New York, v. 38, p. 169-175, 2000. 
POLIZEL, D. M. et al. Performance of lambs fed high concentrate-diets containing monensin or narasin. Journal of Animal Science, Champaign, v. 94, p. 821-822, 2016.

PRESSMAN, B. C. Biological applications of ionophores. Annual Review of Biochemistry, Palo Alto, v. 45, p. 501-530, 1976.

PRESTON, R. L. Management of high concentrate diets in feedlot. In: SIMPÓSIO SOBRE PRODUÇÃO INTENSIVA DE GADO DE CORTE, 1998, Campinas. Anais... Campinas: CBNA, 1988. p. 82-91.

PÜTTER, J. Peroxidases. In: BERGMEYER, H. U. (Ed.). Methods of enzymatic analysis. Weinheim, USA: Verlag Chemie-Academic Press, 1974. p. 685-690. Doi:10.1016/b978-0-12-091302-2.50033-5.

PYE, K. The production of non-wood papermaking fibres by the Alcell process. In: Proc. PIRA Conf. PIRA International, Peterborough, UK, pp. 1-17, 1996.

RADOSTITS, O. M. et al. Clínica veterinária: um tratado de doenças dos bovinos, ovinos, suínos, caprinos e eqüinos. 9. ed. Rio de Janeiro: Guanabara Koogan, 2002.

RANGEL, A. H. N. et al. Utilização de lonóforos na produção de ruminantes. Revista de Biologia e Ciências da Terra, Campina Grande, v. 8, n. 1, p. 264273, 2008.

REILLY, P. M.; SCHILLER, H. J.; BULKLEY, G. B. Pharmacologic approach to tissue injury mediated by free radicals and other reactive oxygen metabolites. The American Journal of Surgery, Belle Mead, v. 161, p. 488-503, 1991.

RESENDE JÚNIOR, J. C. et al. Effect of the feeding pattern on rumen wall morphology of cows and sheep. Brazilian Journal of Veterinary Research and Animal Science, São Paulo, v. 43, n. 4, p. 526-536, 2006.

RICKE, S. C. et al. Influence of dietary fibres on performance and fermentation characteristics of gut contents from growing chicks. Poultry Science, Urbana, v. 61, p. $1335-1343,1982$.

RODRIGUES, J. Siringol - molécula da semana. 2014. Disponível em: <https://www.fciencias.com/2014/12/25/siringol-molecula-da-semana/>. Acesso em: 01 maio 2019.

RONALD, H. A. Gas chromatography mass spectroscopy. In: SETTLE, F. A. (Ed.). Handbook of instrumental techniques for analytical chemistry. Upper Saddle River, NJ: Prentice Hall, 1997. p. 609-611.

RUSSELL, J. B.; STROBEL, H. J. Mini-review: the effect of ionophores on ruminal fermentations. Applied and Environmental Microbiology, Washington, v. 55, p. 1-6, 1989. 
SÁ, E. M. F. A influência da água nas propriedades da carne - Parte II. Revista Nacional da Carne, Rio de Janeiro, v. 28, p. 325, 2004.

SAKATA T. \& TAMATE H. Rumen epithelial cell proliferation accelerated by rapid increase in intraruminal butyrate. Journal of Dairy Science, v.61, p.11091113, 1978.

SALMAN, A. K. D.; PAZIANI, S. F.; SOARES, J. P. G. Utilização de ionóforos para bovinos de corte. Porto Velho - RO: Embrapa Rondônia, 2006. (Documentos, 101).

SHAHIDI, F.; WANASUNDARA, P. K. Phenolic antioxidants. Critical Reviews in Food Science and Nutrition, United States, v. 32, n. 1, p. 67-103, 1992.

SIES, H. Oxidative stress. New York: Academic Press, 1985.

SIES, H.; STAHL, W.; SUNDQUIST, A. R. Antioxidant functions of vitamins. Annals of the New York Academy of Sciences, New York, v. 669, p. 7-20, 1992.

SILVA, H. L. Dietas de Alta Proporção de Concentrados para Bovinos de Corte Confinados. 2009. Tese (Doutorado em Veterinária) - Escola de Veterinária, Universidade Federal de Goiás, Goiânia. 2009.

SMITH, B. P. Medicina interna de grandes animais. 3. ed. São Paulo: Manole, 2006.

SINGH, M., KALLA, N. R., \& SANYAL, S. N. Effect of monensin , a Na + specific carboxylic ionophore on the oxidative defense system in rat testis.

Pharmacological Reports, v.59, p.456-461, 2007.

SORIANI, M.; PIETRAFORTE, D.; MINETTI, M. Antioxidant potential of anaerobic human plasma: role of serum albumin and thiols as scavengers of carbon radicals. Archives of Biochemistry and Biophysics, Amsterdam, v. 312, p. 180-188, 1994.

SOUSA, W, H. et al. Desempenho e características de carcaça de cordeiros terminados em confinamento com diferentes condições corporais. Revista Brasileira de Saúde Produção Animal, Salvador, v. 9, n. 4, p. 795-803, 2008.

SUGINO, N. Roles of reactive oxygen species in the corpus luteum. Animal Science Journal, Tokyo, v. 77, p. 556-565, 2006.

TEDESCHI, L. O.; FOX, D. G.; TYLUTKI, T. P. Potential environmental benefits of ionophores in ruminants diets. Journal of Environmental Quality, Madison, v. 32, p. 1591-1602, 2003.

THE HUMAN Metabolome Database (HMDB). Disponível em: $<$ http://www.hmdb.ca/>. Acesso em: 01 maio 2019. 
TISSERAND, R.; YOUNG, R. Essential oil safety: a guide for health care professionals. 2nd ed. London: Elsevier, 2014.

TÜZÜN, A. et al. Oxidative stress and antioxidant capacity in patients with inflammatory bowel disease. Clinical Biochemistry, Berlin, v. 35, p. 569-572, 2002.

UGARTONDO, V.; MITJANS, M.; VINARDELL, M. P. Comparative antioxidant and cytotoxic effects of lignins from different sources. Bioresource

Technology, Barking, v. 99, p. 6683-6687, 2008.

URANO, F. S. et al. Performance and carcass characteristics of feedlot lambs fed raw soybean. Brazilian Journal of Agricultural Research, Brasília, v. 41, p.1525-1530, 2006.

VAN BERGEN, P. F. et al. Evidence for demethylation of syringyl moieties in archaeological wood using pyrolysis-gas chromatography/mass spectrometry. Rapid Communications in Mass Spectrometry, Chichester, v. 14, p. 71-79, 2000.

VAN CLEEF, E. Distúrbios metabólicos por manejo alimentar inadequado em ruminantes: novos conceitos. Revista Colombiana de Ciência Animal, Sucre, v. 1, n. 2, p. 319-341, 2009.

VAN SOEST, P. J. Nutritional ecology of the ruminant. 2nd ed. Ithaca: Cornell University Press, 1994.

VANCE, C. P.; KILRK, T. K.; SHERWOOD, R. T. Lignification as a mechanism of disease resistance. Annual Review of Phytopathology, Palo Alto, v. 18, p. 259-288, 1980.

VELMURUGAN, N.; HAN, S. S.; LEE, Y. S. Antifungal activity of neutralized wood vinegar with water extracts of Pinus densiflora and Quercus serrata saw dusts. International Journal of Environmental Research, Tehran, v. 3, p. 167-176, 2009.

VYNCKE, W. Evaluation of the Direct Thiobarbituric Acid Extraction Method for Determining Oxidative Rancidity in Mackerel (Scomber scombrus L. Fette, Seifen, Anstrichmittel, v.77(6), p.239-240, 1975.

WANG, $\mathrm{H}$. et al. Antioxidant and antiinflammatory activities of anthocyanins and their aglycon, cyanidin, from tart cherries. Journal of Natural Products, Gorakhpur, v. 62, p. 294-296, 1999.

WANG, Y.; McALLISTER, T. A.; LORA, J. Effects of purified lignin on in vitro rumen metabolism and growth performance of feedlot cattle. AsianAustralasian Journal of Animal Sciences, Seoul, v. 30, n. 3 p. 392-399, 2017. 
WANG, Y. et al. Effect of steroidal saponin from Yucca schidigera extract on ruminal microbes. Journal of Applied Microbiology, Oxford, v. 88, p. 887896, 2000.

WEISS, W. P.; CONRAD, H. R.; PIERRE, R. R. S. A theoretically-based model for predicting total digestible nutrient values of forages and concentrates.

Animal Feed Science and Technology, Amsterdam, v. 39, p. 95-110, 1992.

WILSON, J. R. Organization of forage plant tissues. In: JUNG, H. G. et al. (Eds.). Forage cell wall structure and digestibility. Madison: American Society of Agronomy, 1993. p. 1-32.

WITITSIRI, S. Production of wood vinegars from coconut shells and additional materials for control of termite workers, Odontotermes sp. and striped mealy bugs, Ferrisia virgate. Journal of Science and Technology, Kumasi, v. 33, p. 349-354, 2011. 
ANEXO 


\title{
ANEXO A - Certificado de aprovação pela Comissão de Ética no Uso de Animais
}

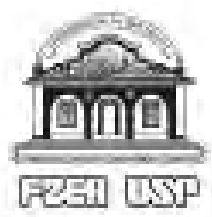

\author{
UNINEKSDACE DESAO PAULO \\ Focubode de Zootecrio en Enor hola de hirences \\ Cemete de thea on Pesquitia da 12 ea
}

\section{CERTIFICADO}

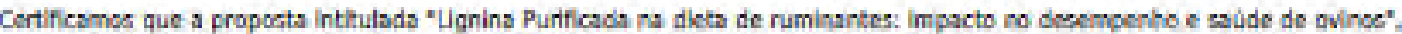
protocolsds sob o CEUA nF 8617140917 , sob a responsahilidade de Paulo Roberto Leme e equipe, Holons Viv Alves Bezorra; Sarita Benagurio Golio - que envolve a producto, manutença elou utillescho de animais pertencenter so filo Onordata, subflio Vertabrata fexceto o homem], para fins de pesquaca cientifica ou ensino. esth de acondo com os proceitos da Le 11.794 de 8 de outubro de 2006, com o Decreto 5.899 de 15 de jaho de 2009, bem como com as normas coltadas pelo Congeho Nacional de Controie da Experimentaçio Animat [CONCFA], e foi aprovada peis Comiscto de Etica no Uso de Animais da Faculdade de Zootocris e Engenharia do Alimertos da Universidade do SSO Pailo - FZEAULGP (CEUA/FZEA) na reunibo de 04/10/2017.

We certiry that the proposal "Purifiod Lignine in ruminants diat: impsct on sheep pertomance and hesth", utrising 32 Ovires (32 males), protocol number CEL,A 8517140917 , under the responsibility of Paulo Roberto Leine and team: Holons Viol Alves Benovra: Santa Bonagurio Gallo - which involves the production, maintenance and/or ise of animals belonging to the phytum Gordsta, subphylum Vertebrato (except human beingsi, for sclentific research purpoes or tesching - is in accordance with lam 11.794 of Detober 8, 2003, Decree 5999 of luly 15, 2009, as well as with the niles iseusd by the Natlonal Councli for Control of Animai Experimentation (CONCEA), and was approved by the Etric Committoe on Animal Lbe of the School of Animal Socence and Food Engineering - (Sta Paulo University) (CEUAVZEA) in the meeting of 10/04/7017.

Finalidade da Proposta; Pesquita (Acandemica)

Vigencis da Praposta: de 10/2017 a 06/2019 Area: Zoctochis

Orgen: Anlmais provenientes de estabelocimentoe comerdals

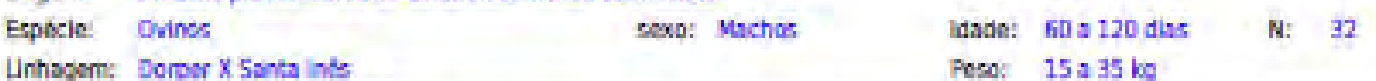

Unhogern: Doroer $\times$ ssota inde

Peso: 15 a 35 ko

Resumo. Este trabaiho tem como abjetivo princiogl avaliar a infobncla de dietas com devada proporça do concentraso contendo lignina bratt como aditivn sobme a saide numinal, desempenho e carscteriaticas da carcaça e da carne de cordeiros e a efeitte antimicroblano da lignira purtilicada na slimentacto de numinontes. Serto utlizados 32 arimais cruzados da naça Dorper X Santa inke, recém desmamados com módia de peso vivo inicial de $15 \mathrm{~kg}$ distribuidos em um defineamento em blocos casualizados divididos em quatro tatamentos: tratamento CTL, em Que os animais serdo almentados com a mça controle, tratamento MON.

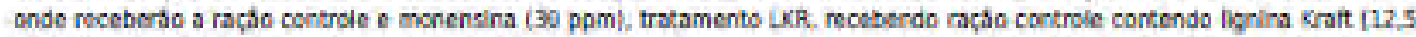

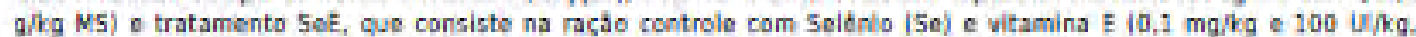
respectivamente). Os animais serdo mantidos em gaiaiss individuais alo/adas em goiplo coberto, sebmetidos a uma dieta

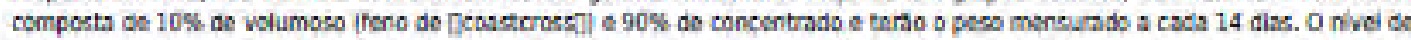
aferts para o primeiro dis de conflinamento sent de $4 \%$ do poso vivo em materia socs, alustando a oferta para concumo ad lbitum (sobras de 10\%) straves do calculo peia pesagem das sotras para média de conseumo indivisual. Serto reallzadas coletas de

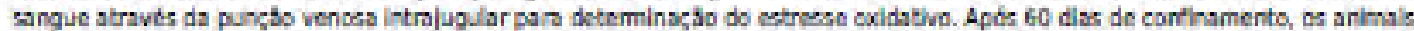
serto abatides e serto ansileadas as caracteristicas como rendimento de carcsch, pH, ospessura de goentura sibcuthnos, ADL e cor, a apos a descose serdo retirsdas amostras que serdo embaladas a vacuo e congeladas dunnte B das para posterier arsilise de maciez. Os resultados serto analisados atravis do prognama 545 versto 9.0 por comparactio do mótas.

Local do experimento: Gaipso experimentai anexo ao CEHER - Departamento on Zootecnis|da Faculdade de Zootacnia e Engermatis do Ailmentos - Campus Femando Costh

Pirasenunga, 04 de outubro de 2017

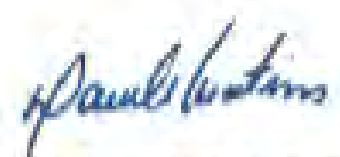

Prota. Dr. Doniele dos Santos Martins Coontensoora da Comiseto de tuca no Uso de knimals

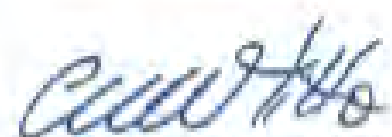

Proh. Dra. Criatisne Gonçalves Thte Vice-Coordeonadon da Comisstio de Ética no Uso de Animsis 